\title{
Bio-telemetry as an Essential Tool in Movement Ecology and Marine Conservation
}

\author{
Brigitte C. Heylen and Dominik A. Nachtsheim
}

\begin{abstract}
Marine top predators represent an essential part of marine ecosystems. They are generally regarded as "sentinels of the sea" since their presence reflects high biological productivity. However, many populations are experiencing dramatic declines attributed to various human-induced threats (e.g., pollution, climate change, overfishing), highlighting the need for effective conservation. In this review, we show that bio-telemetry can be an essential tool, not only to improve knowledge about the animals' ecology, but also for conservation purposes. As such, we will first discuss the most important state-of-the-art devices (e.g., time-depth recorders, accelerometers, satellite tags) and illustrate how they can improve our understanding of movement ecology. We will then examine the challenges and ethical issues related to bio-telemetry, and lastly, demonstrate its enormous value in resolving present and future conservation issues.
\end{abstract}

\section{Introduction}

Marine top predators are widely regarded as potential qualitative indicators of the health and status of marine ecosystems (Burger et al. 2004; Piatt et al. 2007; Boersma 2008; Campbell et al. 2012; Wikelski and Tertitski 2016). Their

B. C. Heylen $(\bowtie)$

Behavioural Ecology and Ecophysiology, University of Antwerp, Antwerp, Belgium

Terrestrial Ecology Unit, Ghent University, Ghent, Belgium e-mail: brigitte.heylen@UGent.be

D. A. Nachtsheim

Institute for Terrestrial and Aquatic Wildlife Research, University of Veterinary Medicine Hannover, Büsum, Germany

BreMarE - Bremen Marine Ecology, Marine Zoology, University of Bremen, Bremen, Germany

e-mail: Dominik.Nachtsheim@tiho-hannover.de responses to changes in the environment can be measured by examining different aspects of their ecology using corresponding methods, for example, foraging behavior (e.g., satellite-linked logging devices and time-depth recorders), energy expenditure (e.g., double-labelled water), stress levels (e.g., corticosteroid hormone concentrations), and diet trends (e.g., stable isotopes and fatty acid analyses) (Votier et al. 2010). The decline of top predators can result in trophic downgrading, which has far reaching consequences on the structure and dynamics of marine ecosystems (Heithaus et al. 2008; Estes et al. 2011; Boaden and Kingsford 2015). At the moment, marine top predators face unprecedented challenges and their future existence is threatened, due to the effects of rapid environmental changes, overfishing, pollution, and many other anthropogenic disturbances (Robinson et al. 2005). If we consider seabirds, for instance, their conservation status has deteriorated faster than any other bird group over recent decades (Croxall et al. 2012; Paleczny et al. 2015). There are also countless examples available for other marine top predators, such as cetaceans (Rosenbaum et al. 2014; McKenna et al. 2015), pinnipeds (Antonelis et al. 2006; Costa et al. 2010a), elasmobranchs (Baum et al. 2003; Graham et al. 2012), and large teleosts (Block et al. 2001; Boyce et al. 2008).

In this review, we focus on the knowledge that can be derived from bio-telemetry and its efficacy in movement ecology and conservation studies. Bio-telemetry can be defined as the remote recording of behavioral, physiological, and environmental data by means of electronic tags, attached to animals (Hays et al. 2016). Here, we use the term biotelemetry synonymously with bio-logging; the latter includes loggers that must be recovered to download the data, which were stored on the device. We aim to give a general overview of existing devices, assess specifically how bio-telemetry can improve our understanding of movement ecology, while taking the negative impacts on the animals into account, and discuss how bio-telemetry can help in recommending conservation measures. 


\section{Existing Bio-telemetry Devices}

We are undoubtedly living in the golden age of bio-telemetry studies (McIntyre 2014; Hussey et al. 2015; Hays et al. 2016). The following section provides an overview of the most commonly used animal-borne bio-telemetry devices and their potential in the context of studying animal behaviors. We start with archival loggers, which can be defined as

\section{Box 1: Quick Guide to Bio-telemetry Terminology \\ Acoustic telemetry: tagged animals are detected and recorded by acoustic receivers at fixed moorings that are recov- ered periodically; this enables tracking of individual animals \\ Archival logger: animal-borne instrument that records and stores data on- board; must be relocated for data download}

Argos satellite tag: animal-borne device that communicates with polar-orbiting Argos satellites to determine its location; typical location errors range between $500 \mathrm{~m}$ and $10 \mathrm{~km}$ Bio-telemetry: method of remote recording of behavioral, physiological and environmental data by electronic tags attached to animals

Fastloc ${ }^{\circledR}$ GPS: $\quad$ takes a snapshot of relevant satellite information in a fraction of a second, when a diving animal surfaces; the calculation of a GPS position is performed on-board the tag, even when not in view of satellites

GPS tag:

GSM:

Global System for Mobile device that determines an animal's position via the Global Positioning System (GPS); typical location errors range between $20 \mathrm{~m}$ and $50 \mathrm{~m}$ Communications; a cellular network that is the global standard for mobile communication, however, also frequently used to relay data from animal-borne instruments (e.g., GPS tags)
Hydrophone: an underwater microphone

Jaw movement sensor: device consisting of Hall sensor and magnet, which are attached to upper and lower mandible, respectively; detects mouth openings and hence feeding events

Pop-up archival transmitting tag (PAT): satellitelinked data logger that is commonly deployed on sharks; logger records and stores temperature, depth and ambient light levels over pre-programmed period until it pops up to the surface and delivers data via the Argos satellite system

Satellite-linked data logger: combination of a satellite tag (Argos and/or GPS) with an archival logger; records an animal's position as well as information on different behaviors and ambient conditions

Stomach temperature logger: device that monitors internal body temperature; a sharp drop in temperature can be attributed to the ingestion of relatively cold prey, enabling the detection of feeding events

Time-depth recorder (TDR): device that records a time-series of dive depths, resulting in time-depth profiles

Tri-axial accelerometer: measures acceleration caused by earth's gravitational field as well as acceleration by the animal in all three space dimensions

Tri-axial magnetometer: measures the orientation towards the earth's magnetic field in all three space dimensions 
instruments that record and store data on-board. This holds true not only for standard time-depth recorders (TDRs), but also for cameras, accelerometers and magnetometers. As they only store the data on-board, one is usually required to recover the instrument and download the data. In the next section we introduce location-only satellite tags. Collecting animal locations is straightforward for Argos satellite tag users, as once they are deployed, the data is relayed and provided online to the user, which enables near real-time tracking. However, this fundamentally differs from global positioning system (GPS) devices, since the position determination works differently. With Argos, the satellite system determines the device's position, while with GPS, the device determines its own position. The latter has the disadvantage that one usually needs to recover the GPS tags, or couple them with satellite or mobile phone networks. Finally, there are tags, which consist of both an archival tag (e.g., TDR, accelerometer, magnetometer) and a satellite tag (e.g., Argos, GPS). These satellite-linked data loggers are the most sophisticated ones and also the ones most commonly used. A 'Quick guide to bio-telemetry terminology' can be found in Box 1.

\section{Archival Loggers}

Archival loggers are deployed on animals to record, in general, movements, specific behaviors, physiological processes or environmental conditions. It is necessary to retrieve these instruments to download data, which can be challenging in highly mobile marine predators. This disadvantage is offset by deploying archival loggers on species with high site fidelity that haul out or breed on land (e.g., elephant seals, seabirds during breeding season), or by combining them with a radio transmitter (Very High Frequency VHF, or Ultra High Frequency - UHF) to relocate the tag when it falls off (Wilson et al. 2002; Dragon et al. 2012; Villegas-Amtmann et al. 2013). Since data transmission is not a constraint for archival loggers, these devices are able to collect data in high-resolution, which are otherwise impossible to obtain and extremely valuable to study finescale processes.

Per Scholander is generally regarded as the pioneer of bio-logging; he deployed the first archival loggers on marine animals in the 1940s (Ropert-Coudert and Wilson 2005; Kooyman 2007; McIntyre 2014). In his famous monograph on diving physiology, he recorded the maximum dive depths of whales, dolphins, and seals by using a capillary tube depth gauge attached to the animal (Scholander 1940; Ponganis 2013). Later, maximum dive depth recorders were used on Weddell seals Leptonychotes weddellii in Antarctica, to study their maximum diving and breath-holding capacities
(DeVries and Wohlschlag 1964). A major step in the history of bio-logging was the development of the first TDR by Gerald Kooyman, which was able to record full time-depth profiles of a dive (Kooyman 1965, 1966). This invention led to fascinating opportunities to study the diving behavior of marine top predators and the related physiological adaptations (Kooyman 1973). At the time, these devices were still quite heavy and, for instance, too large for most bird species. However, due to rapid technological advances, their dimensions have decreased quickly, which means that they can presently be used on a variety of animals (Ropert-Coudert and Wilson 2005; McIntyre 2014; Hussey et al. 2015).

At the same time, improved and additional sensors were included in the classic TDR deployment, enabling diving behavior to be studied in even greater detail. For instance, magnetometers were incorporated, which measure the orientation towards the earth's magnetic field in three axes (heading/yaw, pitch, and roll) and are especially sensitive to record angular rotations (Fig. 1b). Tri-axial magnetometry enables researchers to track three-dimensional movements of diving animals via dead-reckoning, and thus to reconstruct threedimensional profiles of a dive (Davis et al. 1999; Mitani et al. 2003; Wilson et al. 2007; Williams et al. 2017). This was an important improvement, as marine animals inhabit a threedimensional space and respond to environmental cues in all three dimensions. For diving predators both the horizontal and vertical distribution of prey patches is important. Foraging chinstrap penguins Pygoscelis antarctica, for instance, choose to pass by shallow and dense prey aggregations and reach for deeper and more homogenously distributed prey fields with higher encounter probabilities (Zamon et al. 1996) - a finding which would be overlooked in a conventional, two-dimensional analysis of predator-prey distribution. Therefore, taking all three dimensions into consideration is essential to understand fine-scale habitat use or foraging behavior.

At present, it is also common to incorporate accelerometers into archival loggers. These devices measure acceleration, which is caused by earth's gravity (static component) and a change in the animal's speed (dynamic component). It usually records accelerations in three dimensions, the $\mathrm{x}-$, $\mathrm{y}-$, and z-axes or surge, sway, and heave (Fig. 1a). When positioned on the head and/or jaw of a marine predator, accelerometers can provide information about rapid head movements, indicating prey capture attempts (Naito et al. 2010; Kokubun et al. 2011; Gallon et al. 2013). However, accelerometers are often deployed close to the animal's center of gravity, i.e., in the center of the trunk, which is more useful to record overall movement patterns (e.g., swimming, resting, and flying). As such, tri-axial accelerometry can be used to identify and quantify different behaviors and activity patterns, and subsequently, put them in relation to energy 


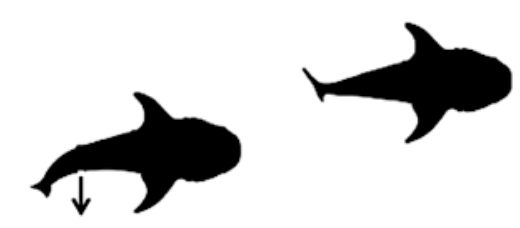

a)
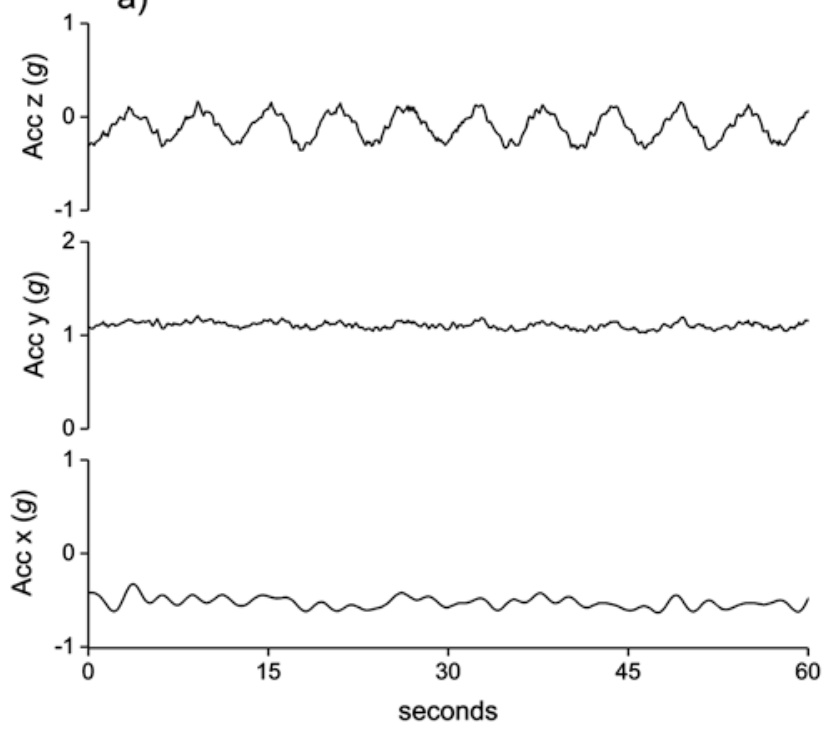

Fig. 1 Swimming behavior of a whale shark Rhincodon typus as indicated by tri-axial (a) accelerometry, and (b) magnetometry. One oscillation corresponds to one tail stroke. Note the weak signal and high degree of noise in the accelerometer data (due to the low stroke fre-

expenditure (Wilson et al. 2006, 2008; Shepard et al. 2008; Sakamoto et al. 2009a). For instance, different at-sea activities (i.e., diving, transiting, resting, and surfacing) during foraging trips of lactating northern fur seals Callorhinus ursinus and Antarctic fur seals Arctocephalus gazella were classified based on accelerometer and dive data. Using these classified behaviors, time-activity budgets were determined and activity-specific energy expenditures were accurately calculated from accelerometer data (Jeanniard-du-Dot et al. 2017). These various applications make accelerometers a powerful and promising tool for future employments.

Video and still-picture cameras are another example of archival loggers, commonly deployed on marine top predators (Fig. 2a) (Moll et al. 2007). These devices not only take photos at regular intervals or record video sequences, but additional incorporated sensors are also able to gather data on environmental conditions (e.g., dive depths and ambient temperature) (Ponganis et al. 2000; Moll et al. 2007; Naito et al. 2010). Over the years, the quality of video footage and photographs has increased substantially, with high-definition cameras being the current status quo (Chapple et al. 2015; Krause et al. 2015; Machovsky-Capuska et al. 2016). High quality recordings require enormous memory capacities; thus the recording time ranges between hours and a few

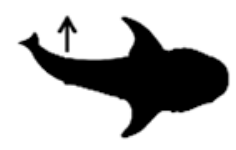

b)
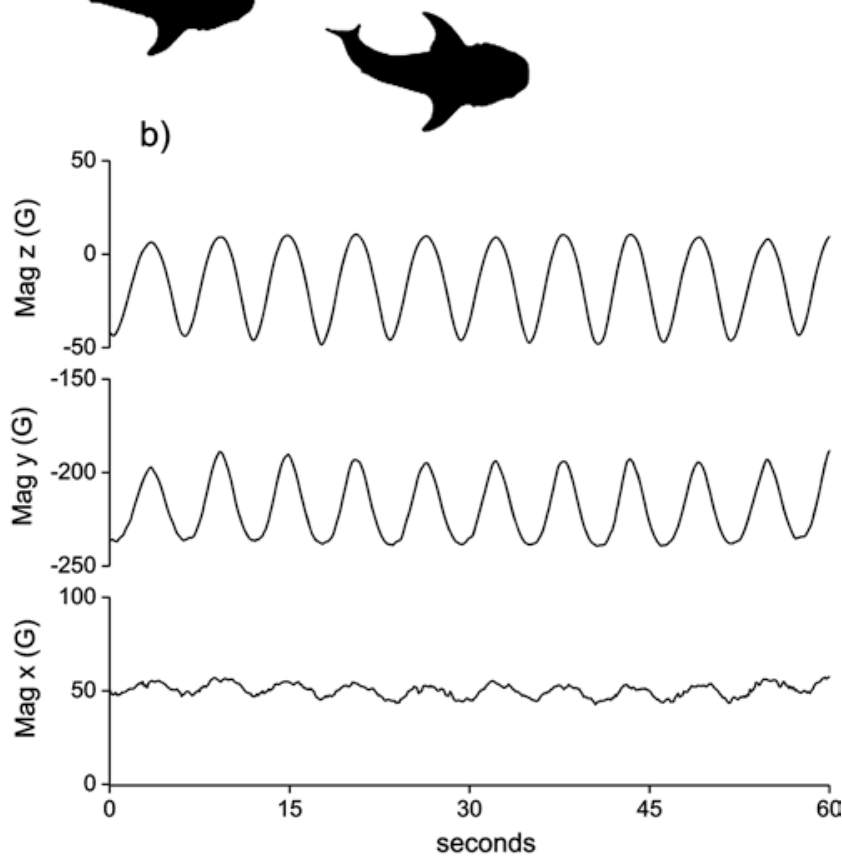

quency). The magnetometer is less susceptible to this noise and is, therefore, better to resolve the angular rotation of the tail strokes. (Reproduced from Williams et al. (2017) (CC-BY 4.0))

days, when a duty cycle is activated. Nevertheless, camera loggers can be extremely valuable tools to obtain direct observations of difficult to observe, and therefore rarely documented, animal behaviors (Takahashi et al. 2004; Sakamoto et al. 2009b; Handley and Pistorius 2016). For example, it could be demonstrated that black-browed albatrosses Thalassarche melanophris actively follow killer whales Orcinus orca and possibly feed on prey remains that were left over by them (Sakamoto et al. 2009b). Such observations are crucial to understand how far-ranging animals locate prey patches in the vast ocean. Camera loggers are also frequently deployed to investigate a predator's foraging behavior in greater detail. Animal-borne imaging can reveal foraging strategies and hunting behavior (Davis et al. 1999; Watanuki et al. 2008; Goldbogen et al. 2012; Krause et al. 2015), quantify prey intake (e.g., Ponganis et al. 2000; Watanabe et al. 2003), or validate prey capture events derived from accelerometers or dive characteristics (Watanabe and Takahashi 2013; Volpov et al. 2015, 2016). Furthermore, cameras attached to diving predators can serve as remote sensors to monitor the surrounding environment. They can, for instance, provide information on the behavior and occurrence of prey species (Fuiman et al. 2002), or detect hitherto unknown faunal communities (Watanabe et al. 2006). 

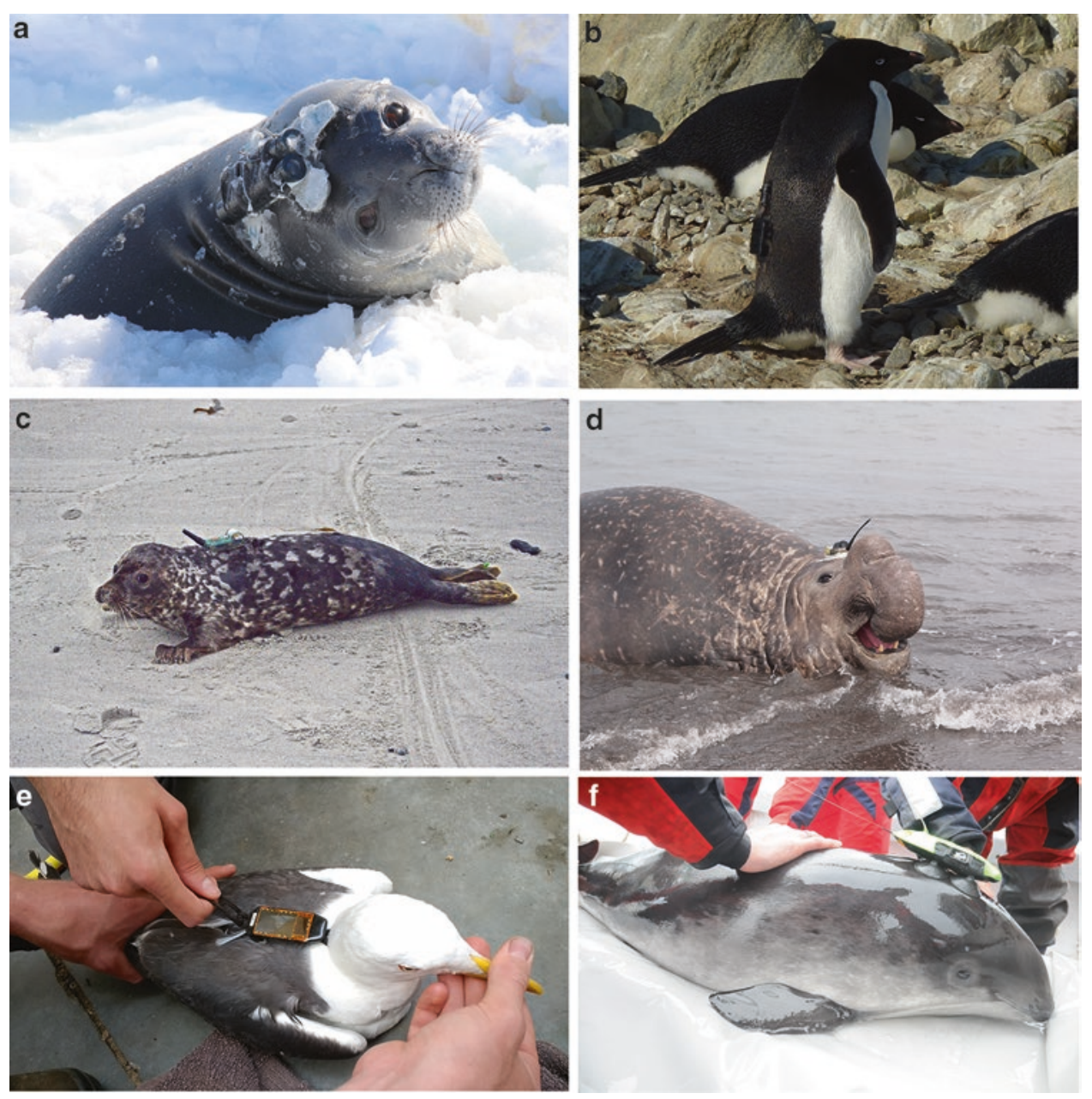

Fig. 2 (a) Adult Weddell seal Leptonychotes weddellii equipped with an infrared camera logger. (b) Adélie penguin Pygoscelis adeliae with GPS and dive logger. (c) Young grey seal Halichoerus grypus with a GSM-relayed Fastloc ${ }^{\circledR}$ GPS data logger, tagged on Helgoland, Germany. (d) Male southern elephant seal Mirounga leonina instrumented with a CTD-Satellite Relay Data Logger on King George Island/Isla 25 de Mayo. (e) Lesser black-backed gull Larus fuscus

Besides these commonly used archival loggers, there are a variety of alternative devices, which record very specific behaviors or physiological processes. Jaw movement sensors are able to detect mouth-opening-events, and can therefore provide a proxy for prey capture attempts (Wilson et al. 2002; Ropert-Coudert et al. 2004; Liebsch et al. 2007). Another measurement used to detect prey capture can be the drop in internal body temperature when relatively cold prey is ingested by marine endotherms. As such, esophagus or stomach temperature loggers have been regularly deployed in seabirds and marine mammals to record feeding activities (Wilson et al. 1992; Ropert-Coudert et al. 2001; Austin et al. 2006a; Ropert-Coudert and Kato 2006). Other sensors are able to record heart rate (Woakes et al. 1995; Hindell and Lea 1998; Froget et al. 2004; Chaise et al. 2017) or flipper strokes (Sato et al. 2003; Insley et al. 2008; Jeanniard-du-Dot et al. 2017) to study field metabolic rates and energy expenditures. tagged with a solar-powered GPS logger and tri-axial accelerometer. (f) Harbor porpoise Phocoena phocoena with a Digital Sound RecordingTag (DTAG), attached by suction cups. Photos used with permission from Dominik Nachtsheim (a), Nina Dehnhard (b), Abbo van Neer (c), Alfred-Wegener-Institut/Horst Bornemann (CC-BY 4.0) (d), Brigitte Heylen (e), and Jonas Teilmann (f)

There are certainly many more archival loggers available for various applications and research questions, however, a discussion of those is beyond the scope of this review.

\section{Argos Satellite Tags}

The Argos satellite system was initiated in the late 1970s and represents a cooperative project between Centre National d'Études Spatiales (CNES) in France, and the National Oceanic and Atmospheric Administration (NOAA) and National Aeronautics and Space Administration (NASA) in the USA. Argos is operated and managed by Collecte Localisation Satellites (CLS) in Toulouse, France. Soon after its initiation, the high importance of Argos satellites for wildlife telemetry studies was recognized. Satellite telemetry was developed as a means of overcoming the logistical difficulties 
and high costs of conventional VHF radio telemetry (Fancy et al. 1988). Animal locations are determined through Doppler shift via communication between an animal-borne satellite transmitter and polar-orbiting satellites. The estimated locations are provided online by CLS and allow quasi-live tracking of tagged individuals (Fancy et al. 1988; Costa et al. 2012).

Argos satellite tags represent the first reliable system to track horizontal movements of marine animals. This information is essential to analyze habitat use or migration patterns. The first successful deployment was conducted on a basking shark Cetorhinus maximus and only provided locations over the course of two weeks (Priede 1984). Nevertheless, this was sufficient to conclude that the shark was probably feeding on zooplankton along a frontal system (Priede 1984; Priede and Miller 2009). Since then, enormous improvements in both the Argos satellite system and satellite tags have been achieved (e.g., more polar-orbiting satellites, better sensitivity of satellite sensors, longer transmitter battery life, more streamlined tag shapes), ultimately leading to a larger quantity of collected data (Hays et al. 2007). Argos satellite tags have been deployed on a diverse assemblage of marine top predator species, including seabirds (Jouventin and Weimerskirch 1990; Spencer et al. 2014; Pistorius et al. 2017), sharks (Priede 1984; Eckert and Stewart 2001; Weng et al. 2005), pinnipeds (Costa et al. 2010a; Dietz et al. 2013; Arcalís-Planas et al. 2015) and cetaceans (Andrews et al. 2008; Edrén et al. 2010; Hauser et al. 2010; Reisinger et al. 2015).

\section{GPS Tags}

Despite the many advantages of Argos satellite tags, one of the major drawbacks is the relatively low location accuracy, with errors generally ranging between $500 \mathrm{~m}$ and $10 \mathrm{~km}$ (Costa et al. 2010b). Qualitatively poor Argos locations are especially prevalent in studies involving diving top predators, since the time spent at the surface to enable successful uplinks to the satellite is limited (Vincent et al. 2002; Costa et al. 2010b; Patterson et al. 2010). GPS tags provide a much better accuracy, usually with errors less than $50 \mathrm{~m}$ (Costa et al. 2010b; Dujon et al. 2014). Despite this higher location accuracy, most researchers have, for quite some time, refrained from using GPS tags, mainly due to the length of time (10 $30 \mathrm{~min}$ ) and high energy demand required to fix a GPS position (Tomkiewicz et al. 2010; Costa et al. 2012). This meant that they were well suited for seabirds (Fig. 2e) (Ryan et al. 2004; Pinaud and Weimerskirch 2007; Votier et al. 2010), but less so for diving animals. This problem has more recently been overcome by the development of a Fastloc ${ }^{\circledR}$ GPS, for which GPS positions can be obtained within milliseconds, which enables a successful location fix even within a short surfacing event (Costa et al. 2010b). Thus, GPS tags are now also increasingly used on marine mammals (Heide-Jørgensen et al. 2013; Villegas-Amtmann et al. 2013; McKenna et al. 2015). The GPS positions are either stored on-board the device and must be downloaded from a recovered tag, or can be transmitted via the Argos satellite system (Costa et al. 2010b; Patterson et al. 2010). GPS locations can also be relayed through communication with the Global Systems for Mobile Communication (GSM) - the mobile phone network (McConnell et al. 2004; Cronin and McConnell 2008). The locations are stored internally and transmitted as a text message, together with ancillary information, when the animal is within the coverage of the GSM network (Cronin and McConnell 2008). These devices represent a promising tool for the relatively inexpensive and accurate tracking of coastal top predator species (Fig. 2c) (Jessopp et al. 2013; Wilson et al. 2017), especially in the light of the rapidly expanding GSM network around the globe.

\section{Satellite-linked Data Loggers}

For many applications, simultaneous information on both horizontal movements and specific behaviors, for example, diving behavior, is required to better understand how marine animals respond to their environment and use their habitat. This is achieved by combining a satellite tag (Argos and/or GPS) with an archival logger (e.g., time-depth recorders, accelerometers), i.e., a satellite-linked data logger. These devices not only record an animal's position, but also log information on different behaviors and ambient conditions. Some instruments are able to transmit these data via Argos satellites, while others need to be recovered for data download. Remotely collected data via satellite only provide compressed and reduced information due to bandwidth limitations, whereas retrievable instruments offer data in high resolution. However, it is expected that the impact of this constraint will continue to lessen with the on-going rapid technological advance and further developments in the field of bio-telemetry (see, for example, Cox et al. 2017).

The first satellite-linked data logger was a combination of a satellite transmitter and a TDR (Merrick et al. 1994). This provided the opportunity to combine location data with concurrent behavioral data, and thus enabled the analysis of horizontal and vertical movements (Merrick et al. 1994; Ryan et al. 2004; Burns et al. 2008; Bestley et al. 2015; Heerah et al. 2016). The first satellite-linked dive recorders were effective to study habitat use in relation to diving behavior, but had restricted applicability, due to the limited information available about each dive (Merrick et al. 1994; Burns 1999; Davis et al. 2007; Nachtsheim et al. 2017). The development of the satellite relay data logger (SRDL) revolutionized the study of top predator movements, providing locations and compressed time-depth profiles for each dive via satellite communication (Fedak et al. 2002). These 
devices can also incorporate high precision environmental sensors, which are able to record valuable CTD (Conductivity, Temperature, Depth) data. The collected temperature and salinity profiles have a relatively good quality and accuracy, compared to traditional oceanographic measurements, such as floats and moorings (Boehme et al. 2009). This development meant that studying foraging behavior in relation to actual environmental conditions, as experienced by the animals, became possible (Fig. 2d) (Biuw et al. 2007; McIntyre et al. 2011; Lowther et al. 2013; Blanchet et al. 2015; Labrousse et al. 2015).

Accelerometers and magnetometers can also be coupled with Argos or GPS devices, providing even more powerful tools to study animal behavior (Fig. 2e) (Wilson et al. 2008; Bouten et al. 2013; Cox et al. 2017). These instruments are able to give extremely detailed information about threedimensional movements and behaviors. More sophisticated devices have also incorporated a hydrophone for sound recordings of diving predators, such as cetaceans, which enables researchers to relate their movements to acoustic behavior as well as to the surrounding soundscape (Fig. 2f) (Nowacek et al. 2001; Johnson and Tyack 2003; Aguilar Soto et al. 2008; Wisniewska et al. 2016). Such instruments usually have to be recovered for data retrieval, but recently other systems have been developed, which allow the remote downloading of concurrent GPS and accelerometer data at ground base stations (Bouten et al. 2013). Another exciting and promising approach is the recent launch of the ICARUS initiative (Icarus Initiative 2018). Specifically-designed ICARUS satellite tags will be

\section{Box 2: Links to Online Databases Hosting Marine Animal Movement Data}

Biodiversity.aq-Antarctic biodiversity data base: http://www.biodiversity.aq

Lifewatch.be-A virtual laboratory for biodiversity research: http://www.lifewatch.be/

OBIS-SEAMAP_Ocean Biogeographic Information System Spatial Ecological Analysis of Megavertebrate Populations: http://seamap.env. duke.edu/

Ocean Tracking network: https://members.oceantrack. org/projects

OCEARCH's Global Shark Tracker: http://www. ocearch.org

MEOP_Marine Mammals Exploring the Oceans from Pole to Pole: http://www.meop.net

MMT-Marine Mammal Tracking: https://www.pangaea.de/?q=project $\% 3$ Alabel\%3AMMT

Movebank: A Database for Animal Tracking Data: https://www.movebank.org able to record GPS positions as well as tri-axial accelerometer data and transmit the data to the ICARUS antenna on-board the International Space Station. The data will then be made available to the users in near real time via the database Movebank (see Box 2 for an overview on databases for animal movement data). These remotely-operating systems enable the study of migration patterns and habitat use of migratory species over large spatial and temporal scales in great detail (Wikelski et al. 2007; Bouten et al. 2013; Stienen et al. 2016; Wikelski and Tertitski 2016).

For animals that do not regularly come to the surface, such as fish, pop-up archival transmitting tags (PATs) can be used (Carlson et al. 2010; Jorgensen et al. 2010; Campana et al. 2011; Hammerschlag et al. 2011). PATs usually constitute an archival logger and an Argos satellite transmitter, and, in the case of sharks and other elasmobranchs, are anchored in the dorsal fin or dorsal musculature (Hammerschlag et al. 2011). The logger records and stores temperature, depth, and ambient light levels over several months to years. After a preprogrammed period, the tag detaches from the animal and pops up to the ocean surface. While floating, it transmits the recorded data to Argos satellites (Hammerschlag et al. 2011). The animal's horizontal movements are reconstructed from the in situ measured sea surface temperature and light levels, resulting in a daily estimate of latitude and longitude. Since the location estimate is relatively imprecise, with mean errors ranging between 60 and $180 \mathrm{~km}$, only large-scale movements and migrations patterns can be investigated (Block et al. 2011; Campana et al. 2011; Hammerschlag et al. 2011). A comparable technology is used to track largescale and often multi-year movements of pinnipeds and flying seabirds, however, this system is not linked to satellites. Similar to PATs, light level geolocators record light levels from which locations can be derived. They are relatively inexpensive and the spatial resolution (ca. 100-200 km) is often sufficient for wide-ranging species, such as petrels, albatrosses, terns, or elephant seals (Afanasyev 2004; Bradshaw et al. 2004; Phillips et al. 2004; Egevang et al. 2010; Weimerskirch et al. 2014).

\section{Acoustic Telemetry}

Tracking animals by means of acoustic telemetry was specifically developed for use in marine and freshwater ecosystems. It is based on the idea that tagged animals, most often fish, are registered by submerged receiving stations (Donaldson et al. 2014; Hussey et al. 2015). The tag is usually a transmitter, which is either surgically implanted or attached externally to the animal and emits signals with a given pulse rate. The transmitters can be miniscule $(<0.5 \mathrm{~g}$ in some cases), and can even be used to tag small or juvenile fish (McMichael et al. 2010). The presence of the animal is recorded when the trans- 
missions are detected by a hydrophone in the receivers. However, the detection efficiency, i.e., the attenuation of sound, varies between different environments and water conditions, which represent a major limitation of acoustic telemetry (Donaldson et al. 2014). Often, multiple acoustic receivers are organized in a comprehensive array or network to cover the pre-defined study area, enabling the tracking of each individual's movements. The data are stored within the receiver station and can either be downloaded by recovering the device or via wireless technology (Dagorn et al. 2007; Donaldson et al. 2014; Hussey et al. 2015). Such acoustic receivers can also be installed on mobile platforms, such as predators, to detect encounters with tagged individuals. This means that interactions between a predator and its prey, as well as spatiotemporal patterns of predator and prey distribution can be studied (Lidgard et al. 2014).

\section{Movement Ecology}

Movement is a fundamental characteristic of many species, and as such, plays an important role in the survival and reproduction of individuals. This, in turn, affects the structure and dynamics of populations and ecosystems. Therefore, to manage marine ecosystems properly, it is imperative to understand the causes, patterns, mechanisms, and consequences of individual movement. Data derived from biotelemetry can provide insight into animals' movement ecology and show interactions within the ecosystem they inhabit (Cagnacci et al. 2010). This enables a mechanistic understanding of movement ecology, including foraging behavior and seasonal migration. However, interpreting biotelemetry data remains a challenge in certain applications, (e.g., habitat modelling), due to the inherent features of telemetry data. These features include spatial and temporal auto-correlation, uneven sampling intervals, uneven sampling effort across individuals and uneven detectability across different habitats (Aarts et al. 2008). Choosing an appropriate analytical approach for the respective research questions is, therefore, crucial. An overview of the currently available methods is described in Carter et al. (2016).

\section{Foraging Behavior}

Optimal foraging theory predicts that every individual strives to minimize its foraging effort, while maximizing its foraging success to assure its survival and reproduction - the drivers for natural selection (MacArthur and Pianka 1966; Schoener 1971; Pyke 1984). For instance, Antarctic fur seals have distinct foraging strategies, with associated trade-offs related to habitat availability, travel costs, prey accessibility and prey quality (Arthur et al. 2016). We can differentiate between top predators that are central place foragers ( $\mathrm{CPFs}$ ), which regularly return to a specific location between foraging trips to feed young, store food, or rest, and thus face spatial constraints on foraging (Orians and Pearson 1979), and roaming foragers, a term we use for all non-CPFs. CPFs prefer foraging habitat near their central place, because, when travel time between the central site and the prey resource increases, their net energy gain decreases (Andersson 1978). For both CPFs and roaming foragers, efficiency is determined by the trade-offs between energy expenditures and gains (Shoji et al. 2016). Individuals may further optimize their foraging efficiency by concentrating on a specific prey type or the exploitation of a specific habitat. In stable environments, specialization in foraging strategies can be highly advantageous as individuals decrease search and handling costs, and reduce their niche overlap with other individuals, thus minimizing competition (Bolnick et al. 2003). A potential cost of specialization is that individuals may lack the flexibility to respond to environmental change (Bolnick et al. 2003; McIntyre et al. 2017). Within the light of rapid environmental change as a result of anthropogenic activities, behavioral plasticity in foraging behavior becomes particularly important. Climate change may affect top predators' geographic ranges and energy balance by altering the distribution and abundance of prey populations (MacLeod 2009; Hazen et al. 2013). Additionally, food resources may change at the local scale due to other anthropogenic influences. Local depletion and competition with fisheries can be regarded as general examples of the latter (Lidgard et al. 2014; Cronin et al. 2016). A topical issue is the future European Union ban on fisheries discards, currently providing a major resource for a wide range of seabird species (Garthe et al. 1996; Furness 2003; Votier et al. 2010, 2013; Bicknell et al. 2013; Krüger et al. 2017).

Specialization may require specific foraging behaviors (Patrick and Weimerskirch 2014). Single individuals may apply multiple foraging strategies or only a single one, or they may temporarily switch between strategies. When individuals use different foraging strategies, their choice may depend on a range of intrinsic and extrinsic factors (Patrick et al. 2013; Camphuijsen et al. 2015). These factors are not mutually exclusive, as the underlying processes influence each other notably. As such, it is difficult to identify the causal effects of each of these factors separately. Therefore, a multifactorial approach is required to investigate their influence on foraging ecology. Integrating multiple types of data at different scales enhances our understanding of a predator's foraging behavior as well as the circumstances that lead to foraging success, as these can differ not only between and within species, but even within individuals depending on the conditions (Austin et al. 2006b; Watanabe and Takahashi 2013; McIntyre et al. 2017).

Intrinsic factors can strongly influence foraging efficiency. One of these factors is age or experience. It is generally 
assumed that older individuals have learned to improve their energy gain and lower their effort per feeding attempt, as illustrated in the Caspian Gull Larus cachinnans (Skórka and Wójcik 2008). Another, more frequently observed defining intrinsic factor of foraging efficiency is sex, which can be observed in many taxa as a possible mechanism to reduce intra-specific competition. Sexually distinct foraging strategies were observed, amongst others, in lesser black-backed gulls Larus fuscus and harbor seals Phoca vitulina (Camphuijsen et al. 2015; Wilson et al. 2015b). A healthy body condition is also vital for efficient foraging. African penguins in low body condition after an energy-demanding breeding season may have difficulties in gaining enough fat reserves to molt, and consequently forage less efficiently as feather quality deteriorates, eventually leading to starvation (Crawford et al. 2011). Lastly, brood demand is also an important factor. In general, when offspring is present, net energy demand is higher, which will affect parental feeding strategies (Pinaud et al. 2005; O'Dwyer et al. 2007; Rishworth et al. 2014; Shoji et al. 2015). Additionally, the increasing energetic demands of developing progeny may make it even harder to deliver sufficient food as the breeding season progresses.
Movement, hence foraging ecology, is also significantly determined by extrinsic factors, such as prey distribution and availability, environmental features, intra- and interspecific competition, and the presence of anthropogenic food sources (Lewis et al. 2001; Grémillet et al. 2004; Biuw et al. 2007; Dragon et al. 2010; Labrousse et al. 2015). For the latter, fisheries discards are one of the most important drivers of seabird distributions (Garthe et al. 1996; Bartumeus et al. 2010; Patrick et al. 2015; Krüger et al. 2017), while recreational fisheries, offshore wind farms, and terrestrial refuse tips can play a role too (Griffiths et al. 2004). Environmental factors, such as sea surface temperature (SST), oceanographic features, sea ice conditions, and atmospheric conditions, are also highly important, since they are the main drivers for prey distribution and availability (Tremblay et al. 2009; Labrousse et al. 2015; Cox et al. 2016). For instance, a study using satellite-linked dive recorders revealed that the distance to the continental shelf break and sea ice concentration were the most important drivers of crabeater seal's Lobodon carcinophaga distribution in the Weddell Sea in the summer of 1998 (Fig. 3) (Nachtsheim et al. 2017). Both their distribution and foraging behavior aligned well with the life

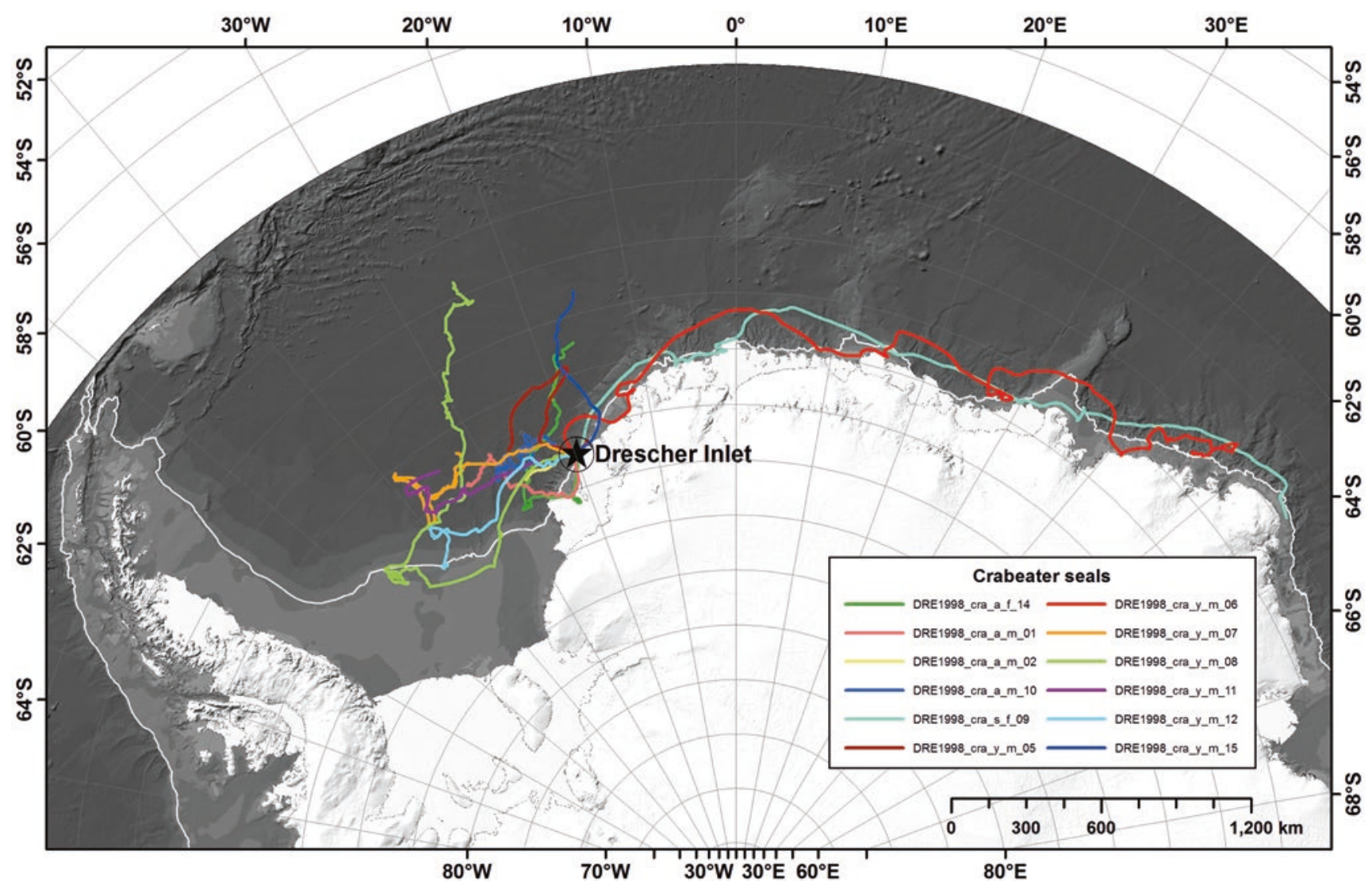

Fig. 3 Tracks of 12 crabeater seals Lobodon carcinophaga in the Weddell Sea dispersing from the tagging location in the Drescher Inlet (star). Each colored line represents an individual track. Bathymetry is indicated by various shades of grey $($ light $=$ shallow, dark $=$ deep $)$. The white line shows the $1000 \mathrm{~m}$ isobath defined as continental shelf break. Ten seals explored the eastern and central Weddell Sea, while two animals moved far eastwards up to $45^{\circ} \mathrm{E}$ along the coast. (Reproduced from Nachtsheim et al. (2017) (CC-BY 4.0)) 
a) Number of profiles in the MEOP-CTD database

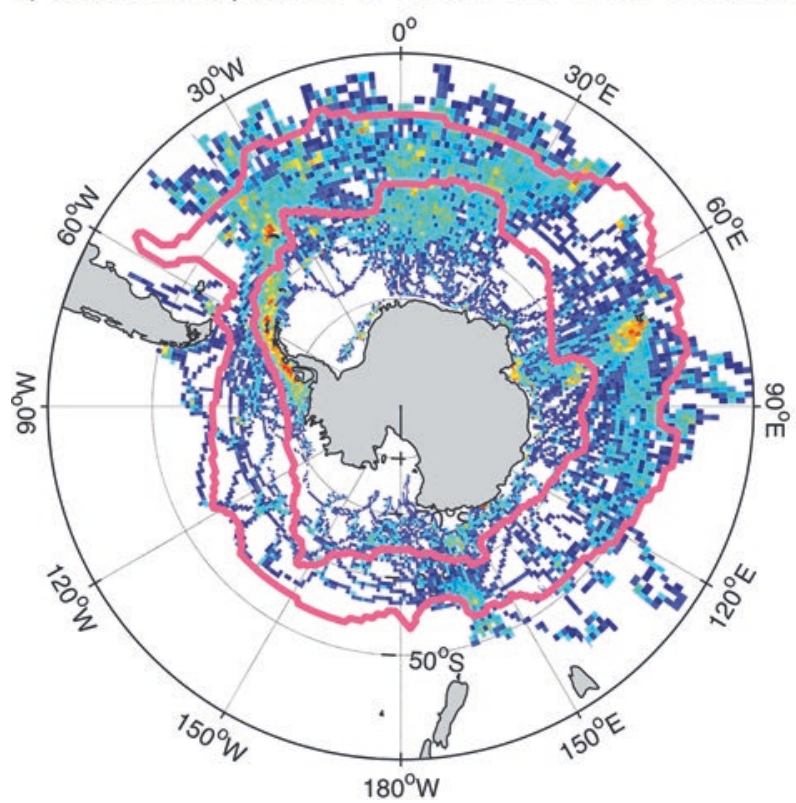

Fig. 4 Number of temperature-salinity profiles of (a) seal-derived data from the Marine mammal Exploring the Oceans Pole to Pole (MEOP) program, and (b) Argo float profiles (see Gould et al. (2004) for more details). Superimposed in pink are the Antarctic Circumpolar Current b) Number of Argo profiles (period 2007-mid2008)
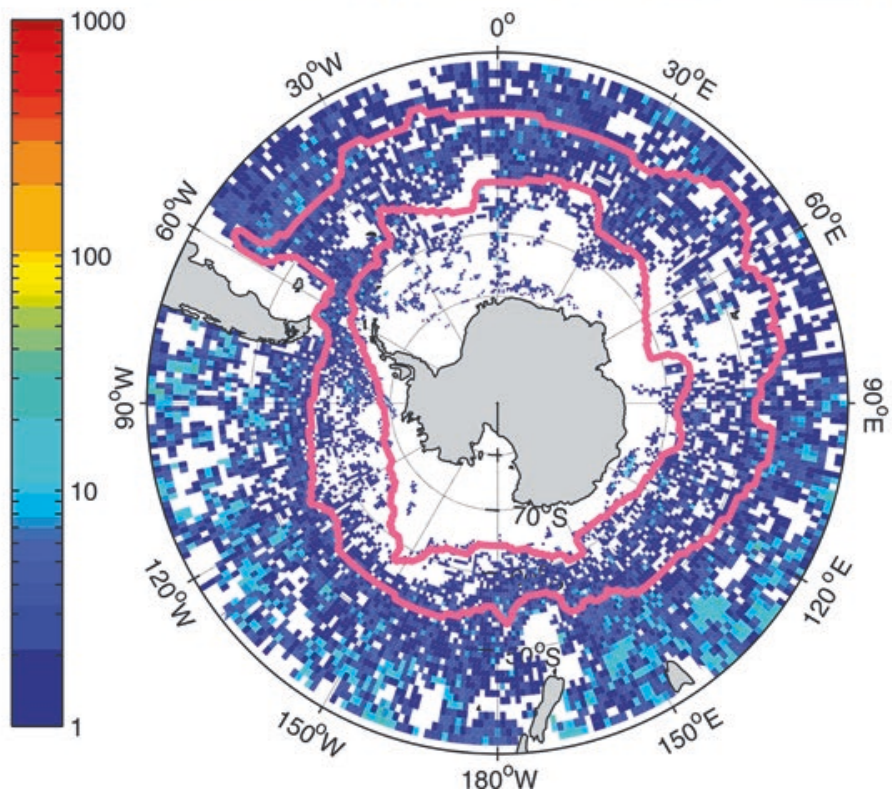

borders. This figure shows clearly how animal-borne devices can complement traditional observations, particularly at places where access is limited (e.g., due to sea ice). (Reproduced from Roquet et al. (2013) (CC-BY 4.0)) history of Antarctic krill Euphausia superba, their preferred prey (Nachtsheim et al. 2017).

Oceanographic and environmental data are readily available online, with the NOAA and the Copernicus program being the largest providers (Copernicus 2017; NOAA 2017), or from the animal-borne devices themselves. The latter sometimes provide physical oceanographic data from areas that cannot be sampled using other conventional approaches (Fig. 4) (Årthun et al. 2012; Roquet et al. 2013). Following this further, detailed oceanographic data could provide information about how marine top predators will probably respond to climatic change (Costa et al. 2010a; McIntyre et al. 2011). For instance, CTD satellite tags deployed on southern elephant seals Mirounga leonina, crabeater seals, and Weddell seals in the Western Antarctic Peninsula have shown that these three species occupy very different habitat types, hence trophic niches, within this region, and will therefore be affected differently by climate change (Costa et al. 2010a). Additionally, many marine top predators feed at depth and several studies have demonstrated the association between oceanographic features of the water column and predator's diving behavior (Fig. 5) (Biuw et al. 2010; Heerah et al. 2013; Guinet et al. 2014). Quantifying foraging effort at depth, based on the detection of changes in diving behavior, can relate the actual behavior of the predator in three dimensions to the heterogeneous environment they respond to (Heerah et al. 2016). For southern elephant seals, the switch from transit to hunting mode was associated with colder water temperatures, relatively short dive bottom time and rapid descent rates (Bestley et al. 2013). As mentioned before, foraging efficiency should be investigated by looking at both horizontal and vertical movements, as this can reveal interesting inter-specific behavioral differences, for example, resource partitioning through different dive behavior in closely related predator species (Wilson 2010; Villegas-Amtmann et al. 2013; Bestley et al. 2015). Information on foraging effort, which is, among others and depending on the species, determined by the number of dives, dive duration, vertical and horizontal travel distance, and the time a foraging trip takes, can be readily derived from conventional tracking data (Boyd et al. 2014). However, the study of movement ecology is lifted to another level by using tri-axial accelerometers combined with GPS loggers, which are able to provide high-resolution behavioral data on the level of decision-making (Wilson et al. 2008; Watanabe and Takahashi 2013; Bidder et al. 2014). For example, by linking GPS and accelerometer data of lesser black-backed gulls, a recent study was able to provide insight into how a flight generalist (i.e., a bird who has the ability to radically alter its flight mode in response to external conditions) can reduce the energetic cost of movement (Shamoun-Baranes et al. 2016). 


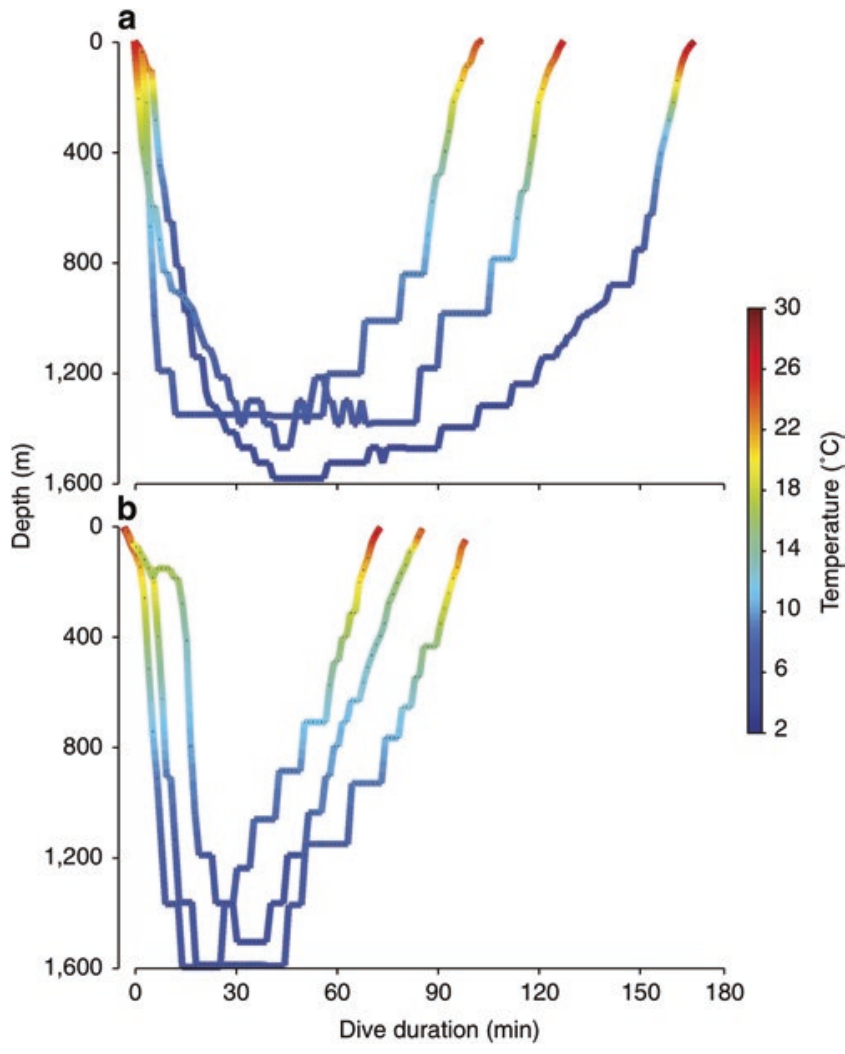

Fig. 5 Depth and temperature profiles from Chilean devil rays Mobula tarapacana, tagged with pop-up satellite archival transmitters during (a) daylight hours (6 a.m. -6 p.m.), and (b) night-time hours (6 p.m. -6 a.m.). These profiles show that devil rays are among the deepest-diving animals, especially at night, albeit shorter in time. (Reproduced from Thorrold et al. (2014) (CC-BY 4.0))

Hydroacoustic surveys can reveal the link between foraging habitat and the distribution of prey, and provide more insight into different aspects of foraging behavior. Although one might assume that predictable prey abundance determines foraging habitats, accessibility is an important factor too, especially for surface foragers, as is the case for Peruvian booby Sula variegata and guanay cormorant Phalacrocorax bougainvilliorum (Boyd et al. 2015). A specific foraging strategy may be influenced by several factors. Foraging range may be determined by the overall distribution of prey, the predators' ability to detect prey may be influenced by the distance between prey patches, and prey capture efficiency may be affected by individual patch characteristics (Carroll et al. 2017). Little penguins Eudyptula minor caught more prey where aggregations were relatively dense, compact and shallow (Carroll et al. 2017). Another study revealed that masked boobies Sula dactylatra from Phillip Island, Australia, showed a trade-off between strong foraging site fidelity around their colony where less prey is available, and more distant foraging trips with less predictable but larger prey patches (Sommerfeld et al. 2015). Temporal differences in foraging behavior can also be observed. For instance, dive depths of most northern elephant seal Mirounga angustirostris showed a clear diel pattern, consistent with targeting vertically migrating prey species (Fig. 5) (Robinson et al. 2012). Pursuing this further by deploying the hydroacoustic devices directly on large marine mammals, a recently developed sonar tag is able to record acoustic backscatter in front of a diving predator, and as such, quantify their prey field (Lawson et al. 2015).

By combining bio-telemetry data with other fine-scale measurements, such as vessel monitoring systems (VMS), we further enhance our multifactorial approach. These VMS are used globally, and since 2005, all fishing vessels in the European Union longer than $15 \mathrm{~m}$ are required to transmit their position through VMS. By looking at the fine-scale overlap between seabirds and fisheries, the ecological effect of foraging in association with fishing vessels can be determined, including carry-over effects, as not all species respond in the same way. For instance, foraging royal albatrosses Diomedea sanfordi showed low rates of overlap with fisheries and it provided them with no ecological advantage (Sugishita et al. 2015). Conversely, fisheries discards are an important part of lesser black-backed gulls' diet in the North Sea (Garthe et al. 1996; Sommerfeld et al. 2016). This is also the case for southern giant petrels Macronectes giganteus, whose non-breeding distribution largely overlap with zones of high fishing intensity off the coast of South America (Krüger et al. 2017). Northern gannets Morus bassanus, on the other hand, showed clear individual differences in discard consumption and foraging behavior (Votier et al. 2010).

To date, as a result of this multifactorial approach, marine scientists encounter new challenges in coordinating and analyzing high resolution datasets gathered across large spatial scales, (e.g., ocean basins). These challenges can only be overcome by means of multidisciplinary collaborations between biologists, oceanographers, statisticians and engineers (Hussey et al. 2015; Hays et al. 2016). Such collaborations can foster the development of new, innovative and cost-effective bio-telemetry approaches and promote cuttingedge analytical techniques.

\section{Migration}

Migration is defined as long-distance movement of individuals, with a temporal recurrence. Some marine top predators move across vast expanses of the marine environment to acquire spatiotemporal variable resources several times a year, annually or across multiple years. One of the most important uses of bio-telemetry is to identify migration routes and their overlap with anthropogenic features. This application is extremely useful for conservation purposes, and will, therefore, be discussed in more detail in section "Conservation". 


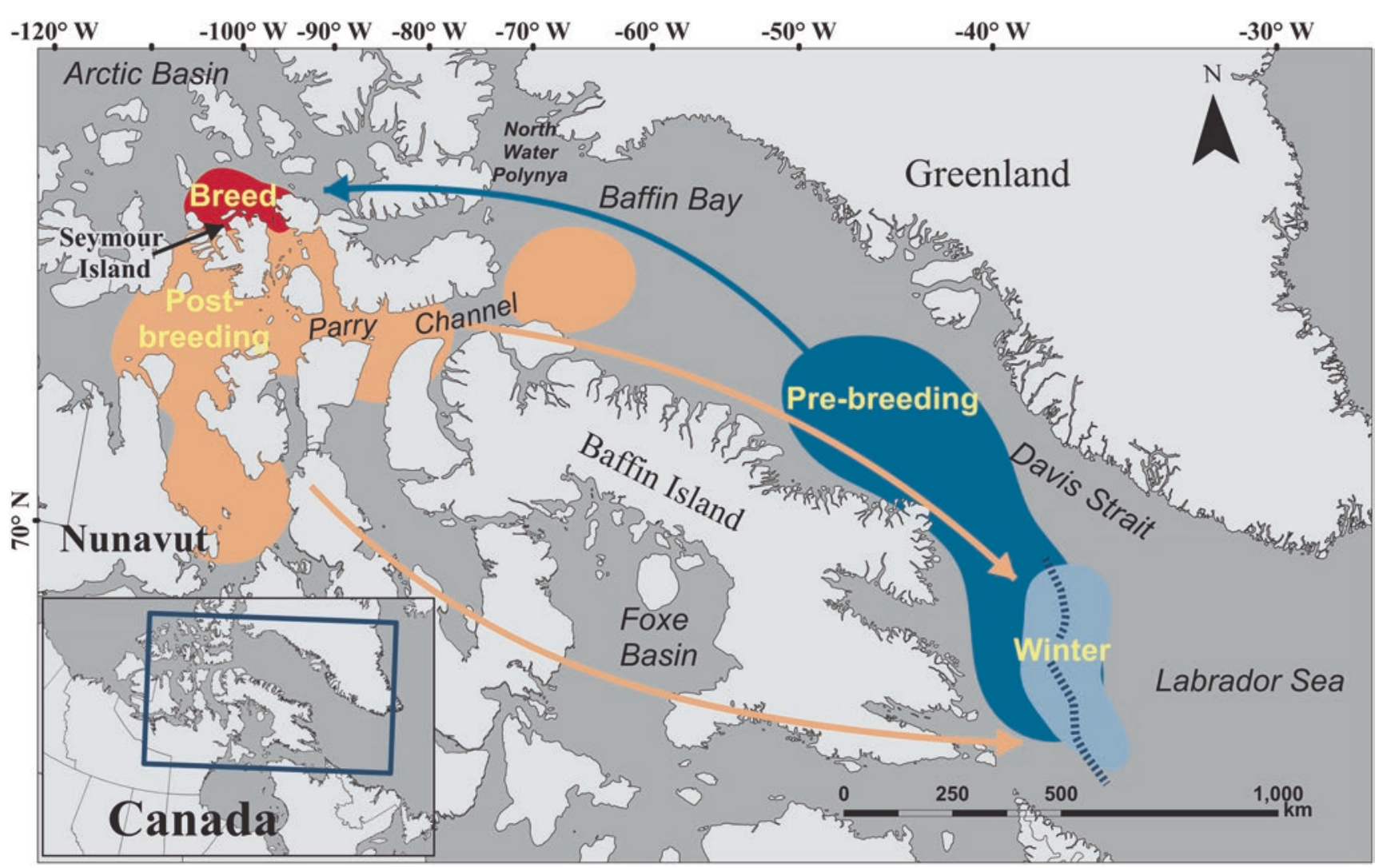

Fig. 6 Annual distribution and migration routes of the ivory gull Pagophila eburnea in the Canadian Arctic. The 50\% kernels represent the general distribution during breeding (red), post-breeding (orange), winter (light blue) and pre-breeding seasons (dark blue). General direction of post-breeding migration is indicated by the orange arrows and direction of pre-breeding migration is indicated by the blue arrow. The dashed line through the winter kernel represents a composite of the typical edge of the pack ice, 2010-2013 (December through April). (Reproduced from Spencer et al. (2014) (CC-BY 4.0))
Various spatiotemporal scales of movement are tied to different life-history functions (Bestley et al. 2009; Block et al. 2011; Putman et al. 2014). Many top predators have evolved life histories that involve travelling large distances between predator-free breeding colonies and areas with large prey abundance (Corkeron and Connor 1999; Costa et al. 2012; Weimerskirch et al. 2012). For example, chinook salmon Oncorhynchus tshawytscha hatch in freshwater, then migrate to the sea where they spend most of their adult life, to ultimately migrate back to freshwater where they spawn and die (Quinn 2005). Long-term observations of these predators' movements provide not only information on the spatial extent of their populations and potential rates of exchange among them, but also expose detailed characteristics of the habitats they use and clues to their navigation abilities (Block et al. 2011; Costa et al. 2012). Bio-telemetry represents a crucial approach to gain this valuable knowledge on migration routes and patterns.

Environmental features undoubtedly influence migration. Analysis of migratory behavior of ivory gulls Pagophila eburnea revealed considerable individual variation of postbreeding migratory route selection, and suggested that the timing of formation/recession and extent of sea ice could play an important role in this (Fig. 6) (Spencer et al. 2014). González-Solís et al. (2009) showed that winds are a major determinant of the migratory routes of three shearwater species, the Manx Puffinus puffinus, the Cory's Calonectris borealis, and the Cape Verde Calonectris edwardsii.

For some species, migration appears to evolve through social learning, for instance in humpback whales Megaptera novaeangliae (Weinrich 1998). However, for many groups, the processes that shape migration routes remain enigmatic, despite the fact that satellite tracking can detail many migratory facets (Block et al. 2011). A particular challenge lies in explaining how juvenile animals, with no prior migratory experience, are able to locate specific oceanic feeding habitats (Lohmann et al. 2008; Gould and Gould 2012). One study showed that juvenile chinook salmon respond to magnetic fields at the latitudinal extremes of their ocean range, which lead towards their marine feeding grounds (Putman et al. 2014). The authors concluded that fish may use a combination of magnetic intensity and inclination angle to assess their geographic location (Putman et al. 2014). Whether this is the case for all migratory species remains to be deter- 
mined. Studies on navigational ability in migratory seabirds showed that there can be many potential cues, for instance, olfactory, hydrodynamic, sky polarization, sun and star positions (Muheim et al. 2006; Lohmann et al. 2008; Gagliardo et al. 2013). However, detecting the geomagnetic field was, for example, in black-browed albatross Diomedea melanophris not one of them (Bonadonna et al. 2003). As such, we need to remind ourselves that experimental studies are never able to look at the full spectrum of natural conditions that occur during migration and, therefore, cannot eliminate particular cues completely.

Bio-telemetry already enables scientists to study the migratory routes of marine top predators in detail. However, at present, many questions remain, especially concerning the drivers and the processes that shape migration. This opens up interesting opportunities for future research and invites scientists to think outside the box to tackle current practical problems. Again, inter- and multidisciplinary collaborations could provide solutions.

\section{Challenges and Ethics of Bio-telemetry}

Attaching a device to an animal necessarily raises ethical questions (Wilson and McMahon 2006), which still remain largely understudied (Vandenabeele et al. 2011). Is it appropriate to equip an animal with an instrument that may impact its natural behavior or may even affect its breeding success and survival? What is regarded as acceptable practice? Does the acquisition of knowledge outweigh the potential adverse effects of a tag? In this section we will first highlight, separately for each top predator group, the difficulties of attaching a tag to an animal, and then list the known tag effects for each group. Finally, we mention approaches for improvements in the field of bio-telemetry and give recommendations from the perspective of animal welfare.

First of all, it is far from easy to equip an animal with a tag. It usually involves capturing and physically restraining the animal for a certain period of time. Sometimes even chemical immobilization is necessary, particularly in large pinnipeds (Gales and Mattlin 1998; Bornemann et al. 2013). The capture itself causes short-term stress for the animal, but does not usually have long-term consequences (Baker and Johanos 2002; McMahon et al. 2005; Blanchet et al. 2014). The tag attachment techniques vary considerably between, and even within, the different taxa, but can generally be divided into invasive and non-invasive attachments.

Most bio-telemetry devices for pinnipeds are non-invasive and commonly glued to the fur by using epoxy resin (Fedak et al. 1983; Lowther et al. 2013; Nachtsheim et al. 2017), or more recently, superglue (Cronin et al. 2016). The devices are either actively recovered or remain on the animal for up to one year until they fall off during the next annual molt.
The attachment procedure itself, i.e., gluing the device to the fur, can cause small superficial abrasions or even lesions in a few cases, however, these injuries heal completely soon after the tag has been shed (Field et al. 2012). There is evidence that the placement of particularly large and bulky tags increases the hydrodynamic drag, potentially causing elevated metabolic costs and leading to behavioral changes in the short term (Walker and Boveng 1995; Hazekamp et al. 2010; Blanchet et al. 2014; Maresh et al. 2015; Rosen et al. 2017). However, long-term studies on the mass gain and survival of seals could not find adverse effects of bio-telemetry devices (Baker and Johanos 2002; McMahon et al. 2008; Mazzaro and Dunn 2010).

The attachment of non-invasive telemetry devices on cetaceans has proven to be challenging. The smooth and rapidly regenerating skin of whales, dolphins and porpoises hampers the attachment of external tags. A commonly used non-invasive method is deploying tags, such as DTAGs, with suction cups (Fig. 2f). These devices usually stay on the animal for a few hours or days (Aguilar Soto et al. 2008; Wisniewska et al. 2016). This method is obviously not sufficient to study large-scale migration patterns and hence, invasive tags are frequently used on cetaceans. The tag is either anchored in the blubber or muscle tissue, especially on large whales and dolphins (Weller 2008; Hauser et al. 2010; Reisinger et al. 2014; Gendron et al. 2015), or pinned through the dorsal fin of small dolphins and porpoises (Irvine et al. 1982; Teilmann et al. 2007; Balmer et al. 2014). While the former can be remotely deployed (e.g., using a crossbow), the latter requires physically capturing the animals. The wound-healing and long-term effects of invasive tagging have rarely been studied, particularly due to the elusive nature of most cetaceans. Although swellings, cavities, and scars are frequently observed at the tag site in large whales, even over a period of multiple years, these injuries, however, had no impact on the body condition, overall health or reproductive success of the animals (Best and Mate 2007; Mate et al. 2007; Weller 2008; Gendron et al. 2015; Norman et al. 2017). In small cetaceans, dorsal fin-mounted tags can fall off due to corrosion of the pins. In some cases, mild inflammatory responses have been reported around the pin holes, but they usually heal without complication, resulting in the formation of scar tissue (Sonne et al. 2012; Heide-Jørgensen et al. 2017). More severe is the migration of dorsal fin tags through the tissue over time due to the constant hydrodynamic drag, ultimately leading to tag loss and fin damage (Irvine et al. 1982; Martin et al. 2006; Balmer et al. 2014). This raises the concern of whether or not such tags negatively affect the natural behavior of small cetaceans (van der Hoop et al. 2014). However, on the long term, body condition, survival rates and reproductive success of tagged small cetaceans were not affected (Martin et al. 2006; HeideJørgensen et al. 2017) 

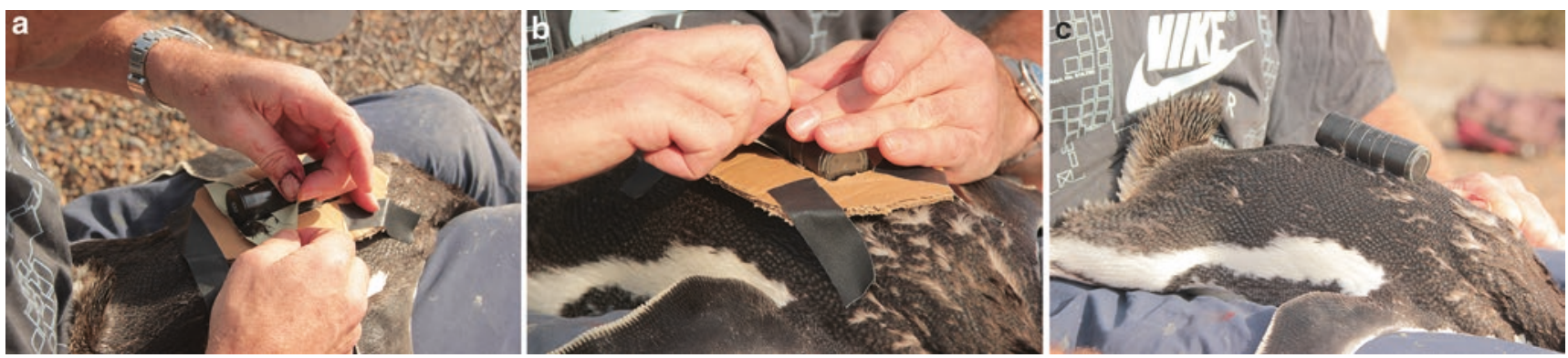

Fig. 7 Different steps of deploying a video camera logger on a Magellanic penguin Spheniscus magellanicus. (a) First, a template is placed on the back of the penguin and Tesa ${ }^{\circledR}$ tape is placed in layers between the feathers. (b) The logger is placed on the back and the tape is wrapped tightly around the device before releasing the penguin back to the nest. (c) After the foraging trip, the tape is removed. (Photos used with permission from William Kay)
Similar problems occur when tagging sharks or other elasmobranchs. Due to their placoid scale epidermis, a noninvasive attachment procedure is almost impossible (Hammerschlag et al. 2011). Most PATs are forcefully implanted into the well-developed dorsal musculature, which reduces the probability of premature release (Carlson et al. 2010; Campana et al. 2011; Hammerschlag et al. 2011). As with dolphins, satellite transmitters are often attached to the shark's dorsal fin using bolts and pins, which can be a source of infection or lead to fin damage (Meyer et al. 2010; Hammerschlag et al. 2011; Jewell et al. 2011). Therefore, new non-invasive attachment methods are currently being tested and further developed. For example, a clamp system was successfully used to attach a combined accelerometer and magnetometer to the second dorsal fin of a whale shark (Fig. 1) (Gleiss et al. 2009; Williams et al. 2017).

Most deployments on seabirds involve the attachment of non-invasive bio-telemetry devices. Most commonly the tags are taped or glued to the back or tail feathers (Fig. 7), carried in a harness or attached to the leg in the form of a band ring (Wilson 1997; Phillips et al. 2003; Shaffer et al. 2005). Depending on the target species, certain attachment methods and locations are discouraged due to known adverse effects. For instance, the use of harnesses may have detrimental effects on petrels and albatrosses, which is why taping to the back feathers is the preferred method (Phillips et al. 2003; Weimerskirch et al. 2007; Mallory and Gilbert 2008). In contrast to other top predators, the effect of tagging has been relatively well studied in seabirds-possibly due to their small size and alarmingly large tags in the past (Wilson et al. 1986). Adult mass, breeding productivity and success, as well as foraging behavior are seemingly not altered and do not differ between tagged and untagged individuals (Phillips et al. 2003; Votier et al. 2004; Chivers et al. 2015; Thaxter et al. 2016). However, for the great skua Stercorarius skua, the over-winter return rate as a measure of survival were substantially lower for tagged than for untagged birds, whereas for the sympatric lesser black-backed gull neither short nor long term effects were reported (Thaxter et al. 2016). Thus, even morphologically similar species can react quite differently to the same animal-borne device. Most of the problems which occur can be attributed to the size of the device, which is traditionally aimed to be below $5 \%$ of the body weight of the bird (Cochran 1980; Phillips et al. 2003), but also to the shape, position and attachment method (Bannasch et al. 1994; Vandenabeele et al. 2014). This extra weight means an increase in energy expenditure during flight of approximately 5\%, without taking into account the increase in drag (Vandenabeele et al. 2012). Thus, large tags can have an influence on the activity budget of seabirds, leading to a reduction of time spent flying (Chivers et al. 2015). Even though humans' movement ecology is somewhat different from that of other animals, we can use the following example to illustrate the possible influence of a tags' weight. If an average sized human with a body weight of $80 \mathrm{~kg}$ was equipped with a device that makes up 5\% of his body weight, he would carry an extra $4 \mathrm{~kg}$ - this is equal the weight of two six packs of canned drinks. If the device was only $1 \%$ of the body weight, the extra weight would constitute $800 \mathrm{~g}$, which is comparable to a small laptop. Since most studies define $3-5 \%$ of the individual's body weight as acceptable practice, but do not take into account the substantial extra energetic costs, we recommend reducing the tag weight load to well below these values, as suggested by Phillips et al. (2003) and Vandenabeele et al. (2012), optimally below $1 \%$ of the body weight.

The tagging of charismatic marine top predators still remains a controversial topic, also within the scientific community (Hazekamp et al. 2010; van der Hoop et al. 2014). However, no adverse long-term effects of bio-telemetry devices were reported for the vast majority of study species. Both the quality and quantity of bio-telemetry data are otherwise impossible to obtain, and tagging studies can immensely enhance our understanding of movements and behavior of marine predators, leading to informed management decisions. These facts advocate the right of bio-telemetry exis- 
tence (McMahon et al. 2012). Nevertheless, there are various valid points in the light of animal welfare that are of concern and must be addressed appropriately. In addition to the increase of drag caused by the attachment of an external device, the extra weight load still represents a major issue for many marine predators.

We believe that, as a further improvement, the scientific community should foster the development of new technologies and the on-going miniaturization of tags. To reduce hydrodynamic drag, Computational Fluid Dynamics (CFD) has proven to be a crucial tool to assess and improve the design of bio-telemetry devices (Pavlov et al. 2007; Balmer et al. 2014). In addition, CFD minimizes the risk of injury and other potentially adverse effects. Furthermore, potential capture and attachment methods for different animal groups should be reviewed and discussed among researchers. It is evident that tag effects must be more thoroughly investigated, and in particular the focus should be directed towards metabolic costs and fitness consequences (McIntyre 2015). It must not be forgotten that we, as scientists, have the responsibility to ensure the wellbeing of the animal. This is not only relevant from an animal welfare viewpoint, but also from a scientific position, as we aim to record and understand the natural behavior of animals in their environment.

\section{Conservation}

The marine environment is predicted to face marked changes by the year 2040 (Brierley and Kingsford 2009), so there is no time to lose. The current challenges require multidisciplinary collaboration to develop effective strategies that rely on an improved understanding of the threat that climate change imposes on species, and the way that it interacts with their natural coping mechanisms (Dawson et al. 2011). Telemetry-derived data have a tremendous potential to inform resource management and conservation, but unfortunately, relatively few examples of their application exist (Wilson et al. 2015a). The financial cost of collecting telemetry data is relatively high, which makes it essential to critically evaluate the conservation benefit of the currently used strategies (McGowan et al. 2017).

One of these strategies, is to combine high resolution biotelemetry data with environmental data and data on anthropogenic activities to build individual-based models, with the aim of predicting habitat use in the (near) future (Grimm et al. 1999; Stillman et al. 2003; Bestley et al. 2013; Stillman et al. 2015; van der Vaart et al. 2016). In these models, different scenarios of anticipated anthropogenically-driven environmental change can be simulated. Once predictive models have been implemented, the outcome can be used for conservation purposes. One extensive study found that modelled physical changes under the Intergovernmental Panel on
Climate Change A2 scenario predict increased species overlap and a potential for niche compression across the North Pacific (Hazen et al. 2013). For species that are already under threat, such changes could exacerbate population declines or inhibit recovery. These models can undoubtedly be used, among other applications, to design marine protected areas (MPAs), which can be a powerful tool for attenuating anthropogenic threats. Several studies have already conducted extensive tracking programs on seabirds to identify foraging hotspots, and used those spatial patterns to inform MPA design (Le Corre et al. 2012; Thaxter et al. 2012; Lascelles et al. 2016).

However, to ensure that these MPAs are highly efficient, adaptive and dynamic management is necessary (Agardy et al. 2003; Maxwell et al. 2015). At present, the majority of marine management approaches (e.g., quota setting, total allowable catches, and MPAs) are relatively static in contrast to the ocean itself and the majority of ocean uses (Agardy 1994; Hyrenbach et al. 2000; Crowder and Norse 2008). Some marine predators are highly mobile and travel great distances over different temporal scales, as is the case, for example, for Arctic terns Sterna paradisaea (Egevang et al. 2010), and gray whales Eschrichtius robustus (Mate et al. 2015). Others, like Atlantic bluefin tuna Thunnus thynnus show complex spatial dynamics, (e.g., homing) and population structure (e.g., several subpopulations of different sizes) (Fromentin and Lopuszanski 2014). To effectively manage this highly dynamic marine system, conservation measures must become more flexible in space and time in the same way as both the environment and the resource users have (Hyrenbach et al. 2000).

A robust understanding of the spatiotemporal distribution and ecology of migratory species is necessary for successful conservation. Conditions experienced during the nonbreeding period may have carry-over effects on breeding performance, which in turn may affect population dynamics (Harrison et al. 2011). Consequently, the anthropogenic impact outside the breeding season also needs to be taken into consideration when making management decisions. Conservation efforts can be targeted at areas where the majority of the population congregate, as is the case for little auks Alle alle at two key areas located in the Greenland Sea and off Newfoundland (Fort et al. 2013).

Fast-acquisition satellite telemetry can provide evidencebased information on individual animal movements to delineate interspecific relationships, and can be used to increase the efficacy of conservation planning (Gredzens et al. 2014). Complimentary co-management, customized for each location, would be advisable when different species use similar habitats (Gredzens et al. 2014). By including data from different species, we obtain more information about commensal foraging associations or multispecies feeding flocks and intra- and interspecific interactions (Barlow et al. 2002; Elliott 
et al. 2010; Lidgard et al. 2012). Areas of predator overlap often occur in regions with high ecological importance, and are therefore useful in designing MPA boundaries. Raymond et al. (2015) used combined tracking data of six species (Adélie Pygoscelis adeliae and emperor Aptenodytes forsteri penguins, light-mantled albatross Phoebetria palpebrata, Antarctic fur seals, southern elephant seals, and Weddell seals) to identify areas of particular ecological significance. These areas were characterized by their proximity to breeding colonies and by sea-ice dynamics, and were therefore considered in the MPA proposal for East Antarctica (Raymond et al. 2015). A similar study used tracking data from 14 different predator species to identify their foraging habitats around the Prince Edward Islands (Reisinger et al. 2018). Amongst others, the results of this study can support the conservation and management of Subantarctic ecosystems and the marine predators they sustain (Reisinger et al. 2018).

Another effective aspect of protective measures can be to establish corridors that link the breeding and foraging grounds of migratory species. One study used a geospatial approach to design a corridor along the north-west coast of Australia that incorporates 11 existing MPAs and overlaps with humpback whale migratory tracks (Pendoley et al. 2014). The study concluded that the proposed network would be beneficial for at least 20 other marine vertebrates, although not all at the same temporal scale (Pendoley et al. 2014).

Establishing pelagic MPAs for oceanic species is another possible measure in adaptive and dynamic management. Biotelemetry can be a useful tool to acknowledge their necessity and to determine their flexible boundaries (Game et al. 2009). For instance, tiger sharks Galeocerdo cuvier were considered to be a reef-associated coastal species, but bio-telemetry actually showed that they display directional movements across ocean basins (Holland et al. 1999; Lowe et al. 2006; Heithaus et al. 2007). Another study determined the primary migratory corridor of gray whales, and concluded that they face a wider range of industrial activities and developments than previously thought (Ford et al. 2012). Protecting far-ranging species can present a major challenge for spatial management, but they are not always equally vulnerable over their entire range (Game et al. 2009). These species often exhibit increased vulnerability in a small number of demographically critical areas, as is the case in wandering albatrosses Diomedea exulans (Weimerskirch et al. 2006). Other species potentially overlap with different human activities during each stage of their migration (e.g., humpback whales) (Rosenbaum et al. 2014). This example highlights the need for adaptive and dynamic management once more, for it would be economically advisable to move the pelagic MPA in space and time synchronously with the whales' migration.

Tracking data can also identify high-use areas and coordinate policy actions that mitigate anthropogenic risks such as those associated with ship strikes, offshore wind farms, oil spills, or bycatch. For instance, manta ray Manta birostris aggregations coincide with some of the busiest shipping lanes (Halpern et al. 2008). This, together with the expansion of megafauna tourism industry, could have an impact on their population numbers (Berman-Kowalewski et al. 2010). However, despite the fact that manta rays forage over large spatial scales $(\sim 100 \mathrm{~km})$ far offshore, they also show high site fidelity and associate with frontal zones (Graham et al. 2012). This knowledge could be used to establish new dynamically protected areas overlaying the frontal region (Graham et al. 2012). Bio-telemetry can also be used to estimate seabirds' vulnerability to offshore wind farms by determining activityspecific and spatially explicit flight heights and collision risks (Cleasby et al. 2015). Another example revealed that $25 \%$ of the North American northern gannet populations migrate annually to the Gulf of Mexico and suffered from severe oiling in the aftermath of the Deepwater Horizon explosion (Montevecchi et al. 2012a, b). These findings contrasted discernibly with available mark-recapture data, and showed that tracking research can be extremely useful when little information on animal distribution in pollution zones is available (Montevecchi et al. 2012a). Tracking data combined with survival and reproduction measurements from their colonies can reveal many possible repercussions of marine pollution, and inform management about conservation concerns (Montevecchi et al. 2012a). Another widespread anthropogenic problem is air-breathing megafauna bycatch. This bycatch intensity varies substantially within and between catch gear and regions (Lewison et al. 2014). Tracking data of marine predators can be overlapped with fisheries data for a dynamic management approach, which could minimize bycatch. For example, an improved understanding of the horizontal and vertical spatiotemporal distribution of North Pacific albatrosses in relation to pelagic fisheries could improve management protocols (e.g., time-area closures and gear mitigation), to reduce the bycatch of these endangered and threatened species (Costa et al. 2012). Lastly, one of the most interesting applications to date is the automated, near-real-time density prediction tool for Eastern North Pacific blue whales Balaenoptera musculus, which enables a more accurate examination of the year-round spatiotemporal overlap of the whales with potentially harmful human activities, such as shipping (Hazen et al. 2016). This study identified high interannual variability in occurrence, emphasizing again the benefit of a dynamic approach (Hazen et al. 2016). Tools like this allow a finer-scale management, which is more economically feasible and socially acceptable (Hazen et al. 2016).

Undoubtedly, there is a necessity for innovative and interdisciplinary approaches, monitoring programs and research initiatives to inform decision makers (Cooke 2008), but it is not only those people who need to be informed. In light of current rapid environmental changes, it is also imperative to engage the general public, and to 
gain their support for conservation. One of the biggest advantages of telemetry is its usefulness in outreach, as this data can be presented in a highly attractive way. However, it is not only their support that is vital. Web-based citizen science projects are a prime example of how volunteers can help process the enormous amount of telemetry-derived data (e.g., through the Zooniverse portal with links to Seabirdwatch, Weddell Seal Count, Snapshots at Sea, Penguin Watch, etc.) (Zooniverse 2017). In general, results from bio-telemetry studies on marine top predators can inform local, regional, and international conservation management, and the general public, which in turn, could trigger actions to mitigate potential anthropogenic threats. To be effective, these management measures should be highly flexible according to the very dynamic nature of marine ecosystems.

\section{Conclusion}

It is evident that tagging marine top predators with biotelemetry devices has an enormous value - not only for studying their movement ecology but also for resolving marine conservation issues. Data from these devices have already answered numerous fundamental questions, and will continue to do so in the future (Hays et al. 2016). The current rapid technological advances will certainly lead to an ever growing variety of new devices and methodological approaches. Nevertheless, animal welfare may not be overlooked. Although no negative long-term effects of biotelemetry devices were reported for most species, there is still potential for improvements. Tag effects must be thoroughly assessed and the miniaturization of bio-telemetry devices must continue to ensure the wellbeing of tagged animals.

In conclusion, adaptive and dynamic management is necessary to guarantee healthy marine ecosystems and this can benefit substantially from monitoring top predators with biotelemetry devices (Maxwell et al. 2015). However, regardless of the management approach, it is clear that multidisciplinary collaboration is key and sharing data is imperative, if conservation is to be successful (Cvitanovic et al. 2015). Additionally, scientists need new tools and frameworks to link animal telemetry-derived data to conservation and management, while maximizing the outcome of the global investment in bio-telemetry devices (McGowan et al. 2017). This will enable us to address the relevant key questions in top predator movement ecology-in conjunction with governments and society - and ultimately lead to effective conservation and management of marine ecosystems.

\section{Appendix}

This article is related to the YOUMARES 8 conference session no. 1: "Sentinels of the Sea: Ecology and Conservation of Marine Top Predators". The original Call for Abstracts and the abstracts of the presentations within this session can be found in the appendix "Conference sessions and Abstracts", chapter "6 Sentinels of the Sea: Ecology and Conservation of Marine Top Predators", of this book.

\section{References}

Aarts G, MacKenzie M, McConnell B et al (2008) Estimating spaceuse and habitat preference from wildlife telemetry data. Ecography 31:140-160. https://doi.org/10.1111/j.2007.0906-7590.05236.x

Afanasyev V (2004) A miniature daylight level and activity data recorder for tracking animals over long periods. Mem Natl Inst Polar Res Spec Issue 58:227-233

Agardy MT (1994) Advances in marine conservation: the role of marine protected areas. Trends Ecol Evol 9:267-270. https://doi. org/10.1016/0169-5347(94)90297-6

Agardy MT, Bridgewater P, Crosby MP et al (2003) Dangerous targets? unresolved issues and ideological clashes around marine protected areas. Aquat Conserv Mar Freshwat Ecosyst 13:353-367. https:// doi.org/10.1002/aqc.583

Aguilar Soto N, Johnson MP, Madsen PT et al (2008) Cheetahs of the deep sea: deep foraging sprints in short-finned pilot whales off Tenerife (Canary Islands). J Anim Ecol 77:936-947. https://doi. org/10.1111/j.1365-2656.2008.01393.x

Andersson M (1978) Optimal foraging area: size and allocation of search effort. Theor Popul Biol 13:397-409

Andrews RD, Pitman RL, Ballance LT (2008) Satellite tracking reveals distinct movement patterns for Type B and Type $\mathrm{C}$ killer whales in the southern Ross Sea, Antarctica. Polar Biol 31:1461-1468. https:// doi.org/10.1007/s00300-008-0487-z

Antonelis GA, Baker JD, Johanos TC et al (2006) Hawaiian monk seal (Monachus schauinslandi): status and conservation. Atoll Res Bull 543:75-101

Arcalís-Planas A, Sveegaard S, Karlsson O et al (2015) Limited use of sea ice by the Ross seal (Ommatophoca rossii), in Amundsen Sea, Antarctica, using telemetry and remote sensing data. Polar Biol 38:445-461. https://doi.org/10.1007/s00300-014-1602-y

Årthun M, Nicholls KW, Makinson K et al (2012) Seasonal inflow of warm water onto the southern Weddell Sea continental shelf, Antarctica. Geophys Res Lett 39:2-7. https://doi. org/10.1029/2012GL052856

Arthur B, Hindell M, Bester MN et al (2016) South for the winter? within-dive foraging effort reveals the trade-offs between divergent foraging strategies in a free-ranging predator. Funct Ecol 30:16231637. https://doi.org/10.1111/1365-2435.12636

Austin D, Bowen WD, McMillan JI et al (2006a) Stomach temperature telemetry reveals temporal patterns of foraging success in a free-ranging marine mammal. J Anim Ecol 75:408-420. https://doi. org/10.1111/j.1365-2656.2006.01057.x

Austin D, Bowen WD, McMillan JI et al (2006b) Linking movement, diving, and habitat to foraging success in a large marine predator. Ecology 87:3095-3108

Baker JD, Johanos TC (2002) Effects of research handling on the endangered Hawaiian monk seal. Mar Mamm Sci 18:500-512. https://doi.org/10.1111/j.1748-7692.2002.tb01051.x 
Balmer BC, Wells RS, Howle LE et al (2014) Advances in cetacean telemetry: a review of single-pin transmitter attachment techniques on small cetaceans and development of a new satellite-linked transmitter design. Mar Mamm Sci 30:656-673. https://doi.org/10.1111/ mms. 12072

Bannasch R, Wilson RP, Culik B (1994) Hydrodynamic aspects of design and attachment of a back-mounted device in penguins. J Exp Biol 194:83-96

Barlow KE, Boyd IL, Croxall JP et al (2002) Are penguins and seals in competition for Antarctic krill at South Georgia? Mar Biol 140:205-213. https://doi.org/10.1007/s00227-001-0691-7

Bartumeus F, Giuggioli L, Louzao M et al (2010) Fishery discards impact on seabird movement patterns at regional scales. Curr Biol 20:215-222. https://doi.org/10.1016/j.cub.2009.11.073

Baum JK, Myers RA, Kehler DG et al (2003) Collapse and conservation of shark populations in the Northwest Atlantic. Science 299:389-392. https://doi.org/10.1126/science.1079777

Berman-Kowalewski M, Gulland FMD, Wilkin S et al (2010) Association between blue whale (Balaenoptera musculus) mortality and ship strikes along the California coast. Aquat Mamm 36:59-66. https://doi.org/10.1578/AM.36.1.2010.59

Best PB, Mate B (2007) Sighting history and observations of southern right whales following satellite tagging off South Africa. J Cetacean Res Manag 9:111-114

Bestley S, Gunn JS, Hindell MA (2009) Plasticity in vertical behaviour of migrating juvenile southern bluefin tuna (Thunnus maccoyii) in relation to oceanography of the south Indian Ocean. Fish Oceanogr 18:237-254. https://doi.org/10.1111/j.1365-2419.2009.00509.x

Bestley S, Jonsen ID, Hindell MA et al (2013) Integrative modelling of animal movement: incorporating in situ habitat and behavioural information for a migratory marine predator. Proc R Soc B Biol Sci 280:2012-2262. https://doi.org/10.1098/rspb.2012.2262

Bestley S, Jonsen ID, Hindell MA et al (2015) Taking animal tracking to new depths: synthesizing horizontal - vertical movement relationships for four marine predators. Ecology 96:417-427. https:// doi.org/10.1890/14-0469.1

Bicknell AWJ, Oro D, Camphuijsen CJ et al (2013) Potential consequences of discard reform for seabird communities. J Appl Ecol 50:649-658. https://doi.org/10.1111/1365-2664.12072

Bidder OR, Campbell HA, Gómez-Laich A et al (2014) Love thy neighbour: automatic animal behavioural classification of acceleration data using the k-nearest neighbour algorithm. PLoS One 9:e88609. https://doi.org/10.1371/journal.pone.0088609

Biuw M, Boehme L, Guinet C et al (2007) Variations in behavior and condition of a Southern Ocean top predator in relation to in situ oceanographic conditions. Proc Natl Acad Sci U S A 104:13705-13710

Biuw M, Nøst OA, Stien A et al (2010) Effects of hydrographic variability on the spatial, seasonal and diel diving patterns of southern elephant seals in the Eastern Weddell Sea. PLoS One 5:e13816. https://doi.org/10.1371/journal.pone.0013816

Blanchet M-A, Lydersen C, Biuw M et al (2014) Instrumentation and handling effects on Antarctic fur seals (Arctocephalus gazella). Polar Res 33:21630. https://doi.org/10.3402/polar.v33.21630

Blanchet M-A, Lydersen C, Ims RA et al (2015) Seasonal, oceanographic and atmospheric drivers of diving behaviour in a temperate seal species living in the high Arctic. PLoS One 10:e0132686. https://doi.org/10.1371/journal.pone.0132686

Block BA, Dewar H, Blackwell SB et al (2001) Migratory movements, depth preferences, and thermal biology of Atlantic bluefin tuna. Science 293:1310-1314. https://doi.org/10.1126/science.1061197

Block BA, Jonsen ID, Jorgensen SJ et al (2011) Tracking apex marine predator movements in a dynamic ocean. Nature 475:86-90. https:// doi.org/10.1038/nature 10082

Boaden AE, Kingsford MJ (2015) Predators drive community structure in coral reef fish assemblages. Ecosphere 6:1-33
Boehme L, Lovell P, Biuw M et al (2009) Technical note: animalborne CTD-satellite relay data loggers for real-time oceanographic data collection. Ocean Sci 5:685-695. https://doi.org/10.5194/ osd-6-1261-2009

Boersma PD (2008) Penguins as Marine Sentinels. Bioscience 58:597_ 607. https://doi.org/10.1641/B580707

Bolnick DI, Svanbäck R, Fordyce JA et al (2003) The ecology of individuals: incidence and implications of individual specialization. Am Nat 161:1-28. https://doi.org/10.1086/343878

Bonadonna F, Chamaillé-Jammes S, Pinaud D et al (2003) Magnetic cues: are they important in Black-browed Albatross Diomedea melanophris orientation? Ibis 145:152-155. https://doi. org/10.1046/j.1474-919X.2003.00117.x

Bornemann H, de Bruyn PJN, Reisinger RR et al (2013) Tiletamine/ zolazepam immobilization of adult post-moult southern elephant seal males. Polar Biol 36:1687-1692. https://doi.org/10.1007/ s00300-013-1378-5

Bouten W, Baaij EW, Shamoun-Baranes J et al (2013) A flexible GPS tracking system for studying bird behaviour at multiple scales. J Ornithol 154:571-580. https://doi.org/10.1007/ s10336-012-0908-1

Boyce DG, Tittensor DP, Worm B (2008) Effects of temperature on global patterns of tuna and billfish richness. Mar Ecol Prog Ser 355:267-276. https://doi.org/10.3354/meps07237

Boyd C, Punt AE, Weimerskirch H et al (2014) Movement models provide insights into variation in the foraging effort of central place foragers. Ecol Modell 286:13-25. https://doi.org/10.1016/j. ecolmodel.2014.03.015

Boyd C, Castillo R, Hunt GL et al (2015) Predictive modelling of habitat selection by marine predators with respect to the abundance and depth distribution of pelagic prey. J Anim Ecol 84:1575-1588. https://doi.org/10.1111/1365-2656.12409

Bradshaw CJA, Hindell MA, Sumner MD et al (2004) Loyalty pays: potential life history consequences of fidelity to marine foraging regions by southern elephant seals. Anim Behav 68:1349-1360. https://doi.org/10.1016/j.anbehav.2003.12.013

Brierley AS, Kingsford MJ (2009) Impacts of climate change on marine organisms and ecosystems. Curr Biol 19:R602-R614. https://doi. org/10.1016/j.cub.2009.05.046

Burger J, Gochfeld M, Serra-Sogas N et al (2004) Marine birds as sentinels of environmental pollution. Ecohealth 1:263-274

Burns JM (1999) The development of diving behavior in juvenile Weddell seals: pushing physiological limits in order to survive. Can J Zool 77:737-747

Burns JM, Hindell MA, Bradshaw CJA et al (2008) Fine-scale habitat selection of crabeater seals as determined by diving behavior. Deep Res Part II 55:500-514. https://doi.org/10.1016/j.dsr2.2007.11.012

Cagnacci F, Boitani L, Powell RA et al (2010) Animal ecology meets GPS-based radiotelemetry: a perfect storm of opportunities and challenges. Philos Trans R Soc Lond B Biol Sci 365:2157-2162. https://doi.org/10.1098/rstb.2010.0107

Campana SE, Dorey A, Fowler M et al (2011) Migration pathways, behavioural thermoregulation and overwintering grounds of blue sharks in the Northwest Atlantic. PLoS One 6:e16854. https://doi. org/10.1371/journal.pone.0016854

Campbell SJ, Hoey AS, Maynard J et al (2012) Weak compliance undermines the success of no-take zones in a large government-controlled marine protected area. PLoS One 7:1-12. https://doi.org/10.1371/ journal.pone. 0050074

Camphuijsen CJ, Shamoun-Baranes J, Van Loon EE et al (2015) Sexually distinct foraging strategies in an omnivorous seabird. Mar Biol 162:1417-1428. https://doi.org/10.1007/s00227-015-2678-9

Carlson JK, Ribera MM, Conrath CL et al (2010) Habitat use and movement patterns of bull sharks Carcharhinus leucas determined using pop-up satellite archival tags. J Fish Biol 77:661-675. https:// doi.org/10.1111/j.1095-8649.2010.02707.x 
Carroll G, Jonsen I, Cox M et al (2017) Hierarchical influences of prey distribution on patterns of prey capture by a marine predator. Funct Ecol. https://doi.org/10.1111/1365-2435.12873

Carter MID, Bennett KA, Embling CB et al (2016) Navigating uncertain waters: a critical review of inferring foraging behaviour from location and dive data in pinnipeds. Mov Ecol 4:25. https://doi. org/10.1186/s40462-016-0090-9

Chaise LL, Paterson W, Laske TG et al (2017) Implantation of subcutaneous heart rate data loggers in southern elephant seals (Mirounga leonina). Polar Biol. https://doi.org/10.1007/s00300-017-2144-x

Chapple TK, Gleiss AC, Jewell OJD et al (2015) Tracking sharks without teeth: a non-invasive rigid tag attachment for large predatory sharks. Anim Biotelem 3:14. https://doi.org/10.1186/s40317-015-0044-9

Chivers LS, Hatch SA, Elliott KH (2015) Accelerometry reveals an impact of short-term tagging on seabird activity budgets. Condor Ornithol Appl 118:159-168. https://doi.org/10.1650/ CONDOR-15-66.1

Cleasby IR, Wakefield ED, Bearhop S et al (2015) Three-dimensional tracking of a wide-ranging marine predator: flight heights and vulnerability to offshore wind farms. J Appl Ecol 52:1474-1482. https://doi.org/10.1111/1365-2664.12529

Cochran WW (1980) Wildlife telemetry. In: Schemnitz SD (ed) Wildlife management techniques manual. Wildlife Society, Washington, DC, pp 507-520

Cooke SJ (2008) Biotelemetry and biologging in endangered species research and animal conservation: relevance to regional, national, and IUCN Red List threat assessments. Endanger Species Res 4:165-185. https://doi.org/10.3354/esr00063

Copernicus (2017) Satellite Earth observation and in situ (non-space) data. http://www.copernicus.eu/. Accessed 11 Nov 2017

Corkeron PJ, Connor RC (1999) Why do baleen whales migrate. Mar Mamm Sci 15:1228-1245. https://doi. org/10.1111/j.1748-7692.1999.tb00887.x

Costa DP, Huckstadt LA, Crocker DE et al (2010a) Approaches to studying climatic change and its role on the habitat selection of Antarctic pinnipeds. Integr Comp Biol 50:1018-1030. https://doi. org/10.1093/icb/icq054

Costa DP, Robinson PW, Arnould JPY et al (2010b) Accuracy of ARGOS locations of pinnipeds at-sea estimated using Fastloc GPS. PLoS One 5:e8677. https://doi.org/10.1371/journal.pone.0008677

Costa DP, Breed GA, Robinson PW (2012) New insights into pelagic migrations: implications for ecology and conservation. Annu Rev Ecol Evol Syst 43:73-96. https://doi.org/10.1146/ annurev-ecolsys-102710-145045

Cox SL, Miller PI, Embling CB et al (2016) Seabird diving behaviour reveals the functional significance of shelf-sea fronts as foraging hotspots. R Soc Open Sci 3:160317

Cox SL, Orgeret F, Gesta M et al (2017) Processing of acceleration and dive data on-board satellite relay tags to investigate diving and foraging behaviour in free-ranging marine predators. Methods Ecol Evol. https://doi.org/10.1111/2041-210X.12845

Crawford R, Altwegg R, Barham B et al (2011) Collapse of South Africa's penguins in the early 21 st century. African J Mar Sci 33:139-156. https://doi.org/10.2989/1814232X.2011.572377

Cronin MA, McConnell BJ (2008) SMS seal: a new technique to measure haul-out behaviour in marine vertebrates. J Exp Mar Bio Ecol 362:43-48. https://doi.org/10.1016/j.jembe.2008.05.010

Cronin MA, Gerritsen H, Reid D et al (2016) Spatial overlap of grey seals and fisheries in Irish waters, some new insights using telemetry technology and VMS. PLoS One 11:e0160564. https://doi. org/10.1371/journal.pone.0160564

Crowder L, Norse E (2008) Essential ecological insights for marine ecosystem-based management and marine spatial planning. Mar Policy 32:772-778. https://doi.org/10.1016/j.marpol.2008.03.012
Croxall JP, Butchart SHM, Lascelles B et al (2012) Seabird conservation status, threats and priority actions: a global assessment. Bird Conserv Int 22:1-34. https://doi.org/10.1017/S0959270912000020

Cvitanovic C, Hobday AJ, van Kerkhoff L et al (2015) Improving knowledge exchange among scientists and decision-makers to facilitate the adaptive governance of marine resources: a review of knowledge and research needs. Ocean Coast Manag 112:25-35. https://doi.org/10.1016/j.ocecoaman.2015.05.002

Dagorn L, Pincock D, Girard C et al (2007) Satellite-linked acoustic receivers to observe behavior of fish in remote areas. Aquat Living Resour 20:307-312. https://doi.org/10.1051/alr:2008001

Davis RW, Fuiman LA, Williams TM et al (1999) Hunting behavior of a marine mammal beneath the Antarctic fast ice. Science 283:993996. https://doi.org/10.1126/science.283.5404.993

Davis RW, Jaquet N, Gendron D et al (2007) Diving behavior of sperm whales in relation to behavior of a major prey species, the jumbo squid, in the Gulf of California, Mexico. Mar Ecol Prog Ser 333:291-302. https://doi.org/10.3354/meps333291

Dawson TP, Jackson ST, House JI et al (2011) Beyond predictions: biodiversity conservation in a changing climate. Science 332:53-58. https://doi.org/10.1126/science.1200303

DeVries AL, Wohlschlag DE (1964) Diving depths of the Weddell seal. Science 145:292. https://doi.org/10.1126/science.145.3629.292

Dietz R, Teilmann J, Andersen SM et al (2013) Movements and site fidelity of harbour seals (Phoca vitulina) in Kattegat, Denmark, with implications for the epidemiology of the phocine distemper virus. ICES J Mar Sci 70:186-195

Donaldson MR, Hinch SG, Suski CD et al (2014) Making connections in aquatic ecosystems with acoustic telemetry monitoring. Front Ecol Environ 12:565-573. https://doi.org/10.1890/130283

Dragon AC, Monestiez P, Bar-Hen A et al (2010) Linking foraging behaviour to physical oceanographic structures: Southern elephant seals and mesoscale eddies east of Kerguelen Islands. Prog Oceanogr 87:61-71. https://doi.org/10.1016/j.pocean.2010.09.025

Dragon AC, Bar-Hen A, Monestiez P et al (2012) Horizontal and vertical movements as predictors of foraging success in a marine predator. Mar Ecol Prog Ser 447:243-257. https://doi.org/10.3354/ meps09498

Dujon AM, Lindstrom RT, Hays GC (2014) The accuracy of FastlocGPS locations and implications for animal tracking. Methods Ecol Evol 5:1162-1169. https://doi.org/10.1111/2041-210X.12286

Eckert SA, Stewart BS (2001) Telemetry and satellite tracking of whale sharks, Rhincodon typus, in the Sea of Cortez, Mexico, and the north Pacific Ocean. Environ Biol Fishes 60:299-308

Edrén SMC, Wisz MS, Teilmann J et al (2010) Modelling spatial patterns in harbour porpoise satellite telemetry data using maximum entropy. Ecography 33:698-708. https://doi. org/10.1111/j.1600-0587.2009.05901.x

Egevang C, Stenhouse IJ, Phillips RA et al (2010) Tracking of Arctic terns Sterna paradisaea reveals longest animal migration. Proc Natl Acad Sci 107:2078-2081. https://doi.org/10.1073/ pnas.0909493107

Elliott KH, Gaston AJ, Crump D (2010) Sex-specific behavior by a monomorphic seabird represents risk partitioning. Behav Ecol 21:1024-1032. https://doi.org/10.1093/beheco/arq076

Estes JA, Terborgh J, Brashares JS et al (2011) Trophic downgrading of planet Earth. Science 333:301-306. https://doi.org/10.1126/ science. 1205106

Fancy SG, Pank LF, Douglas DC et al (1988) Satellite telemetry: a new tool for wildlife research and management. Fish Wildl Serv 172:1-54

Fedak MA, Anderson SS, Curry MG (1983) Attachment of a radio tag to the fur of seals. J Zool 200:298-300. https://doi. org/10.1111/j.1469-7998.1983.tb05794.x 
Fedak MA, Lovell P, McConnell B et al (2002) Overcoming the constraints of long range radio telemetry from animals: getting more useful data from smaller packages. Integr Comp Biol 42:3-10. https://doi.org/10.1093/icb/42.1.3

Field IC, Harcourt RG, Boehme L et al (2012) Refining instrument attachment on phocid seals. Mar Mammal Sci 28:1-9. https://doi. org/10.1111/j.1748-7692.2011.00519.x

Ford JKB, Durban JW, Ellis GM et al (2012) New insights into the northward migration route of gray whales between Vancouver Island, British Columbia, and southeastern Alaska. Mar Mamm Sci 29:325-337. https://doi.org/10.1111/j.1748-7692.2012.00572.x

Fort J, Moe B, Strøm H et al (2013) Multicolony tracking reveals potential threats to little auks wintering in the North Atlantic from marine pollution and shrinking sea ice cover. Divers Distrib 19:1322-1332. https://doi.org/10.1111/ddi.12105

Froget G, Butler PJ, Woakes AJ et al (2004) Heart rate and energetics of free-ranging king penguins (Aptenodytes patagonicus). J Exp Biol 207:3917-3926. https://doi.org/10.1242/jeb.01232

Fromentin J-M, Lopuszanski D (2014) Migration, residency, and homing of bluefin tuna in the western Mediterranean Sea. ICES J Mar Sci 71:510-518. https://doi.org/10.1093/icesjms/fst157

Fuiman LA, Davis RW, Williams TM (2002) Behavior of midwater fishes under the Antarctic ice: observations by a predator. Mar Biol 140:815-822. https://doi.org/10.1007/s00227-001-0752-y

Furness RW (2003) Impacts of fisheries on seabird communities. Sci Mar 67:33-45. https://doi.org/10.3989/scimar.2003.67s233

Gagliardo A, Bried J, Lambardi P et al (2013) Oceanic navigation in Cory's shearwaters: evidence for a crucial role of olfactory cues for homing after displacement. J Exp Biol 216:2798-2805. https://doi. org/10.1242/jeb.085738

Gales NJ, Mattlin RH (1998) Fast, safe, field-portable gas anesthesia for otariids. Mar Mamm Sci 14:355-361. https://doi. org/10.1111/j.1748-7692.1998.tb00727.x

Gallon S, Bailleul F, Charrassin JB et al (2013) Identifying foraging events in deep diving southern elephant seals, Mirounga leonina, using acceleration data loggers. Deep Res Part II Top Stud Oceanogr 88-89:14-22. https://doi.org/10.1016/j.dsr2.2012.09.002

Game ET, Grantham HS, Hobday AJ et al (2009) Pelagic protected areas: the missing dimension in ocean conservation. Trends Ecol Evol 24:360-369. https://doi.org/10.1016/j.tree.2009.01.011

Garthe S, Camphuijsen CJ, Furness RW (1996) Amounts of discards by commercial fisheries and their significance as food for seabirds in the North Sea. Mar Ecol Prog Ser 136:1-11. https://doi. org/10.3354/meps 136001

Gendron D, Martinez Serrano I, Ugalde de la Cruz A et al (2015) Long-term individual sighting history database: an effective tool to monitor satellite tag effects on cetaceans. Endanger Species Res 26:235-241

Gleiss AC, Norman B, Liebsch N et al (2009) A new prospect for tagging large free-swimming sharks with motion-sensitive data-loggers. Fish Res 97:11-16. https://doi.org/10.1016/j.fishres.2008.12.012

Goldbogen JA, Calambokidis J, Friedlaender AS et al (2012) Underwater acrobatics by the world's largest predator: $360^{\circ}$ rolling manoeuvres by lunge-feeding blue whales. Biol Lett 9:20120986. https://doi.org/10.1098/rsbl.2012.0986

González-Solís J, Felicísimo A, Fox JW et al (2009) Influence of sea surface winds on shearwater migration detours. Mar Ecol Prog Ser 391:221-230. https://doi.org/10.3354/meps08128

Gould J, Roemmich D, Wijffels S, Freeland H, Ignaszewsky M, Jianping X, Takeuchi K et al (2004) Argo profiling floats bring new era of in situ ocean observations. Eos Trans AGU 85(19):185-191

Gould JL, Gould CG (2012) Nature's compass. The mystery of animal navigation. Princeton University Press, Princeton

Graham RT, Witt MJ, Castellanos DW et al (2012) Satellite tracking of manta rays highlights challenges to their conservation. PLoS One 7:e36834. https://doi.org/10.1371/journal.pone.0036834
Gredzens C, Marsh H, Fuentes MMPB et al (2014) Satellite tracking of sympatric marine megafauna can inform the biological basis for species co-management. PLoS One 9:e98944. https://doi.org/10.1371/ journal.pone.0098944

Grémillet D, Dell'Omo G, Ryan PG et al (2004) Offshore diplomacy or how seabirds mitigate intra-specific competition: a case study based on GPS tracking of Cape Gannets from neighbouring breeding colonies. Mar Ecol Prog Ser 268:265-279. https://doi.org/10.3354/ meps 268265

Griffiths CL, Van Sittert L, Best PB et al (2004) Impacts of human activities on marine animal life in the Benguela: a historical overview. Oceanogr Mar Biol Annu Rev 42:303-392

Grimm V, Wyszomirski T, Aikman D et al (1999) Individual-based modelling and ecological theory: synthesis of a workshop. Ecol Modell 115:275-282. https://doi.org/10.1016/S0304-3800(98)00186-0

Guinet C, Vacquié-Garcia J, Picard B et al (2014) Southern elephant seal foraging success in relation to temperature and light conditions: insight into prey distribution. Mar Ecol Prog Ser 499:285-301. https://doi.org/10.3354/meps 10660

Halpern BS, Walbridge S, Selkoe KA et al (2008) A global map of human impact on marine ecosystems. Science 319:948-952. https:// doi.org/10.1126/science.1149345

Hammerschlag N, Gallagher AJ, Lazarre DM (2011) A review of shark satellite tagging studies. J Exp Mar Bio Ecol 398:1-8. https://doi. org/10.1016/j.jembe.2010.12.012

Handley JM, Pistorius P (2016) Kleptoparasitism in foraging gentoo penguins Pygoscelis papua. Polar Biol 39:391-395. https://doi. org/10.1007/s00300-015-1772-2

Harrison XA, Blount JD, Inger R et al (2011) Carry-over effects as drivers of fitness differences in animals. J Anim Ecol 80:4-18. https:// doi.org/10.1111/j.1365-2656.2010.01740.x

Hauser N, Zerbini AN, Geyer Y et al (2010) Movements of satellitemonitored humpback whales, Megaptera novaeangliae, from the Cook Islands. Mar Mamm Sci 26:679-685. https://doi. org/10.1111/j.1748-7692.2009.00363.x

Hays GC, Bradshaw CJA, James MC et al (2007) Why do Argos satellite tags deployed on marine animals stop transmitting? J Exp Mar Bio Ecol 349:52-60. https://doi.org/10.1016/j. jembe.2007.04.016

Hays GC, Ferreira LC, Sequeira AMM et al (2016) Key questions in marine megafauna movement ecology. Trends Ecol Evol 31:463475. https://doi.org/10.1016/j.tree.2016.02.015

Hazekamp AAH, Mayer R, Osinga N (2010) Flow simulation along a seal: the impact of an external device. Eur J Wildl Res 56:131-140. https://doi.org/10.1007/s10344-009-0293-0

Hazen EL, Jorgensen S, Rykaczewski RR et al (2013) Predicted habitat shifts of Pacific top predators in a changing climate. Nat Clim Chang 3:234-238. https://doi.org/10.1038/nclimate1686

Hazen EL, Palacios DM, Forney KA et al (2016) WhaleWatch: a dynamic management tool for predicting blue whale density in the California Current. J Appl Ecol 54:1415-1428. https://doi. org/10.1111/1365-2664.12820

Heerah K, Andrews-Goff V, Williams G et al (2013) Ecology of Weddell seals during winter: influence of environmental parameters on their foraging behaviour. Deep Res Part II 88-89:23-33. https:// doi.org/10.1016/j.dsr2.2012.08.025

Heerah K, Hindell MA, Andrew-Goff V et al (2016) Contrasting behaviour between two populations of an ice-obligate predator in East Antarctica. Ecol Evol 7:606-618. https://doi.org/10.1002/ ece 3.2652

Heide-Jørgensen MP, Laidre KL, Nielsen NH et al (2013) Winter and spring diving behavior of bowhead whales relative to prey. Anim Biotelem 1:15. https://doi.org/10.1186/2050-3385-1-15

Heide-Jørgensen MP, Nielsen NH, Teilmann J et al (2017) Long-term tag retention on two species of small cetaceans. Mar Mamm Sci 33:713-725. https://doi.org/10.1111/mms.12394 
Heithaus MR, Wirsing AJ, Dill LM et al (2007) Long-term movements of tiger sharks satellite-tagged in Shark Bay, Western Australia. Mar Biol 151:1455-1461. https://doi.org/10.1007/s00227-006-0583-y

Heithaus MR, Frid A, Wirsing AJ et al (2008) Predicting ecological consequences of marine top predator declines. Trends Ecol Evol 23:202-210. https://doi.org/10.1016/j.tree.2008.01.003

Hindell MA, Lea M-A (1998) Heart rate, swimming speed, and estimated oxygen consumption of a free-ranging Southern elephant seal. Physiol Zool 71:74-84. https://doi.org/10.1086/515890

Hindell MA, Harcourt R, Waas JR et al (2002) Fine-scale threedimensional spatial use by diving, lactating female Weddell seals Leptonychotes weddellii. Mar Ecol Prog Ser 242:275-284. https:// doi.org/10.3354/Meps242275

Holland KN, Wetherbee BM, Lowe CG et al (1999) Movements of tiger sharks (Galeocerdo cuvier) in coastal Hawaiian waters. Mar Biol 134:665-673. https://doi.org/10.1007/s002270050582

Hussey NE, Kessel ST, Aarestrup K et al (2015) Aquatic animal telemetry: a panoramic window into the underwater world. Science 348:1255642. https://doi.org/10.1126/science.1255642

Hyrenbach KD, Forney KA, Dayton PK (2000) Marine protected areas and ocean basin management. Aquat Conserv Mar Freshwat Ecosyst 10:437-458. https://doi.org/10.1017/CBO9781107415324.004

Icarus Initiative (2018) International cooperation for animal research using space. https://icarusinitiative.org/. Accessed 20 Nov 2017

Insley SJ, Robson BW, Yack T et al (2008) Acoustic determination of activity and flipper stroke rate in foraging northern fur seal females. Endanger Species Res 4:147-155. https://doi.org/10.3354/esr00050

Irvine AB, Wells RS, Scott MD (1982) An evaluation of techniques for tagging small Odontocete Cetaceans. Fish Bull 80:135-143

Jeanniard-du-Dot T, Guinet C, Arnould JPY et al (2017) Accelerometers can measure total and activity-specific energy expenditures in freeranging marine mammals only if linked to time-activity budgets. Funct Ecol 31:377-386. https://doi.org/10.1111/1365-2435.12729

Jessopp M, Cronin M, Hart T (2013) Habitat-mediated dive behavior in free-ranging grey seals. PLoS One 8:e63720. https://doi. org/10.1371/journal.pone.0063720

Jewell OJD, Wcisel MA, Gennari E et al (2011) Effects of smart position only (SPOT) tag deployment on white sharks Carcharodon carcharias in South Africa. PLoS One 6:e27242. https://doi. org/10.1371/journal.pone.0027242

Johnson MP, Tyack PL (2003) A digital acoustic recording tag for measuring the response of wild marine mammals to sound. IEEE J Ocean Eng 28:3-12. https://doi.org/10.1109/JOE.2002.808212

Jorgensen SJ, Reeb CA, Chapple TK et al (2010) Philopatry and migration of Pacific white sharks. Proc Biol Sci 277:679-688. https://doi. org/10.1098/rspb.2009.1155

Jouventin P, Weimerskirch H (1990) Satellite tracking of Wandering albatrosses. Nature 343:746-748

Kokubun N, Kim J, Shin H et al (2011) Penguin head movement detected using small accelerometers: a proxy of prey encounter rate. J Exp Biol 214:3760-3767. https://doi.org/10.1242/jeb.058263

Kooyman GL (1965) Techniques used in measuring diving capacities of Weddell seals. Polar Rec 12:391-394

Kooyman GL (1966) Maximum diving capacities of the Weddell seal, Leptonychotes weddelli. Science 151:1553-1554. https://doi. org/10.1126/Science.151.3717.1553

Kooyman GL (1973) Respiratory adaptations in marine mammals. Am Zool 13:457-468

Kooyman GL (2007) Animal-borne instrumentation systems and the animals that bear them: then (1939) and now (2007). Mar Technol Soc J 41:6-8. https://doi.org/10.4031/002533207787441935

Krause DJ, Goebel ME, Marshall GJ et al (2015) Novel foraging strategies observed in a growing leopard seal (Hydrurga leptonyx) population at Livingston Island, Antarctic Peninsula. Anim Biotelem 3:24. https://doi.org/10.1186/s40317-015-0059-2
Krüger L, Paiva VH, Petry MV et al (2017) Seabird breeding population size on the Antarctic Peninsula related to fisheries activities in non-breeding ranges off South America. Antarct Sci. https://doi. org/10.1017/S0954102017000207

Labrousse S, Vacquié-Garcia J, Heerah K et al (2015) Winter use of sea ice and ocean water mass habitat by southern elephant seals: the length and breadth of the mystery. Prog Oceanogr 137:52-68. https://doi.org/10.1016/j.pocean.2015.05.023

Lascelles BG, Taylor PR, Miller MGR et al (2016) Applying global criteria to tracking data to define important areas for marine conservation. Divers Distrib 22:422-431

Lawson GL, Hückstädt LA, Lavery AC et al (2015) Development of an animal-borne "sonar tag" for quantifying prey availability: test deployments on northern elephant seals. Anim Biotelem 3:22. https://doi.org/10.1186/s40317-015-0054-7

Le Corre M, Jaeger A, Pinet P et al (2012) Tracking seabirds to identify potential Marine Protected Areas in the tropical western Indian Ocean. Biol Conserv 156:83-93. https://doi.org/10.1016/j. biocon.2011.11.015

Lewis S, Sherratt TN, Hamer KC et al (2001) Evidence of intra-specific competion for food in a pelagic seabird. Nature 412:816-818

Lewison RL, Crowder LB, Wallace BP et al (2014) Global patterns of marine mammal, seabird, and sea turtle bycatch reveal taxa-specific and cumulative megafauna hotspots. Proc Natl Acad Sci USA 111:5271-5276. https://doi.org/10.1073/pnas.1318960111

Lidgard DC, Bowen WD, Jonsen ID et al (2012) Animal-borne acoustic transceivers reveal patterns of at-sea associations in an uppertrophic level predator. PLoS One 7:e48962. https://doi.org/10.1371/ journal.pone.0048962

Lidgard DC, Bowen WD, Jonsen ID et al (2014) Predator-borne acoustic transceivers and GPS tracking reveal spatiotemporal patterns of encounters with acoustically tagged fish in the open ocean. Mar Ecol Prog Ser 501:157-168. https://doi.org/10.3354/meps10670

Liebsch N, Wilson RP, Bornemann H et al (2007) Mouthing off about fish capture: jaw movement in pinnipeds reveals the real secrets of ingestion. Deep Res Part II 54:256-269. https://doi.org/10.1016/j. dsr2.2006.11.014

Lohmann KJ, Lohmann CMF, Endres CS (2008) The sensory ecology of ocean navigation. J Exp Biol 211:1719-1728. https://doi. org/10.1242/jeb.015792

Lowe CG, Wetherbee BM, Meyer CG (2006) Using acoustic telemetry monitoring techniques to quantify movement patterns and site fidelity of sharks and giant trevally around French Frigate Shoals and Midway Atoll. Atol Res Bull 543:281-303

Lowther AD, Harcourt RG, Page B et al (2013) Steady as he goes: at-sea movement of adult male Australian sea lions in a dynamic marine environment. PLoS One 8:e74348. https://doi.org/10.1371/ journal.pone. 0074348

MacArthur RH, Pianka ER (1966) On optimal use of a patchy environment. Am Nat 100:603-609

Machovsky-Capuska GE, Priddel D, Leong PHW et al (2016) Coupling bio-logging with nutritional geometry to reveal novel insights into the foraging behaviour of a plunge-diving marine predator. New Zeal J Mar Freshwat Res 50:418-432. https://doi.org/10.1080/0028 8330.2016.1152981

MacLeod CD (2009) Global climate change, range changes and potential implications for the conservation of marine cetaceans: a review and synthesis. Endanger Species Res 7:125-136. https://doi. org/10.3354/esr00197

Mallory ML, Gilbert CD (2008) Leg-loop harness design for attaching external transmitters to seabirds. Mar Ornithol 36:183-188

Maresh JL, Adachi T, Takahashi A et al (2015) Summing the strokes: energy economy in northern elephant seals during large-scale foraging migrations. Mov Ecol 3:22. https://doi.org/10.1186/ s40462-015-0049-2 
Martin AR, Da Silva VMF, Rothery PR (2006) Does radio tagging affect the survival or reproduction of small cetaceans? a test. Mar Mamm Sci 22:17-24. https://doi.org/10.1111/j.1748-7692.2006.00002.x

Mate BR, Mesecar R, Lagerquist B (2007) The evolution of satellitemonitored radio tags for large whales: one laboratory's experience. Deep Res Part II Top Stud Oceanogr 54:224-247. https://doi. org/10.1016/j.dsr2.2006.11.021

Mate BR, Ilyashenko VY, Bradford AL et al (2015) Critically endangered western gray whales migrate to the eastern North Pacific. Biol Lett 11:20150071. https://doi.org/10.1098/rsbl.2015.0071

Maxwell SM, Hazen EL, Lewison RL et al (2015) Dynamic ocean management: defining and conceptualizing real-time management of the ocean. Mar Policy 58:42-50. https://doi.org/10.1016/j. marpol.2015.03.014

Mazzaro LM, Dunn JL (2010) Descriptive account of long-term health and behavior of two satellite-tagged captive harbor seals Phoca vitulina. Endanger Species Res 10:159-163. https://doi.org/10.3354/ esr00190

McConnell B, Beaton R, Bryant Eet al (2004) Phoning home-a new GSM mobile phone telemetry system to collect mark-recapture data. Mar Mamm Sci 20:274-283. https://doi.org/10.1111/j.1748-7692.2004. tb01156.x

McGowan J, Beger M, Lewison RL et al (2017) Integrating research using animal-borne telemetry with the needs of conservation management. J Appl Ecol 54:423-429. https://doi. org/10.1111/1365-2664.12755

McIntyre T (2014) Trends in tagging of marine mammals: a review of marine mammal biologging studies. African J Mar Sci 36:409-422. https://doi.org/10.2989/1814232X.2014.976655

McIntyre T (2015) Animal telemetry: tagging effects. Science 349:596-597

McIntyre T, Ansorge IJ, Bornemann H et al (2011) Elephant seal dive behaviour is influenced by ocean temperature: implications for climate change impacts on an ocean predator. Mar Ecol Prog Ser 441:257-272. https://doi.org/10.3354/meps09383

McIntyre T, Bester M, Bornemann $\mathrm{H}$ et al (2017) Slow to change? individual fidelity to three-dimensional foraging habitats in southern elephant seals Mirounga leonina. Anim Behav 127:91-99

McKenna MF, Calambokidis J, Oleson EM et al (2015) Simultaneous tracking of blue whales and large ships demonstrates limited behavioral responses for avoiding collision. Endanger Species Res 27:219-232. https://doi.org/10.3354/esr00666

McMahon CR, van den Hoff J, Burton HR (2005) Repeated handling and invasive research methods in wildlife research: impacts at the population level. Ambio 34:426-429

McMahon CR, Field IC, Bradshaw CJA et al (2008) Tracking and datalogging devices attached to elephant seals do not affect individual mass gain or survival. J Exp Mar Bio Ecol 360:71-77. https://doi. org/10.1016/j.jembe.2008.03.012

McMahon CR, Harcourt R, Bateson P et al (2012) Animal welfare and decision making in wildlife research. Biol Conserv 153:254-256. https://doi.org/10.1016/j.biocon.2012.05.004

McMichael GA, Eppard MB, Carlson TJ et al (2010) The juvenile salmon acoustic telemetry system: a new tool. Fisheries 35:9-22

Merrick RL, Loughlin TR, Antonelis GA et al (1994) Use of satellitelinked telemetry to study Steller sea lion and northern fur seal foraging. Polar Res 13:105-114

Meyer CG, Papastamatiou YP, Holland KN (2010) A multiple instrument approach to quantifying the movement patterns and habitat use of tiger (Galeocerdo cuvier) and Galapagos sharks (Carcharhinus galapagensis) at French Frigate Shoals, Hawaii. Mar Biol 157:1857-1868. https://doi.org/10.1007/s00227-010-1457-x

Mitani, Y., Sato, K., Ito, S., Cameron, M. F., Siniff, D. B., \& Naito, Y. (2003). A method for reconstructing three-dimensional dive profiles of marine mammals using geomagnetic intensity data: results from two lactating Weddell seals. Polar Biology, 26(5), 311-317
Moll RJ, Millspaugh JJ, Beringer J et al (2007) A new "view" of ecology and conservation through animal-borne video systems. Trends Ecol Evol 22:660-668. https://doi.org/10.1016/j.tree.2007.09.007

Montevecchi W, Fifield D, Burke C et al (2012a) Tracking long-distance migration to assess marine pollution impact. Biol Lett 8:218-221. https://doi.org/10.1098/rsbl.2011.0880

Montevecchi W, Hedd A, McFarlane Tranquilla L et al (2012b) Tracking seabirds to identify ecologically important and high risk marine areas in the western North Atlantic. Biol Conserv 156:6271. https://doi.org/10.1016/j.biocon.2011.12.001

Muheim R, Phillips JB, Akesson S (2006) Polarized light cues underlie compass calibration in migratory songbirds. Science 313:837-839. https://doi.org/10.1126/science.1129709

Nachtsheim DA, Jerosch K, Hagen W et al (2017) Habitat modelling of crabeater seals (Lobodon carcinophaga) in the Weddell Sea using the multivariate approach Maxent. Polar Biol 40:961-976. https:// doi.org/10.1007/s00300-016-2020-0

Naito Y, Bornemann H, Takahashi A et al (2010) Fine-scale feeding behavior of Weddell seals revealed by a mandible accelerometer. Polar Sci 4:309-316. https://doi.org/10.1016/j.polar.2010.05.009

NOAA (2017) National Oceanographic and Atmospheric Administration. http://www.noaa.gov/. Accessed 11 Nov 2017

Norman SA, Flynn KR, Zerbini AN et al (2017) Assessment of wound healing of tagged gray (Eschrichtius robustus) and blue whales (Balaenoptera musculus) in the eastern North Pacific using long-term series of photographs. Mar Mammal Sci. https://doi. org/10.1111/mms. 12443

Nowacek DP, Johnson MP, Tyack PL et al (2001) Buoyant balaenids: the ups and downs of buoyancy in right whales. Proc R Soc B 268:1811-1816. https://doi.org/10.1098/rspb.2001.1730

O'Dwyer TW, Buttemer WA, Priddel DM (2007) Differential rates of offspring provisioning in Gould's petrels: are better feeders better breeders? Aust J Zool 55:155-160. https://doi.org/10.1071/ ZO07005

Orians G, Pearson N (1979) On the theory of central place foraging. In: Horn DJ, Mitchell R, Stair G (eds) Analysis of ecological systems. Ohio State University Press, Columbus, pp 155-177

Paleczny M, Hammill E, Karpouzi V et al (2015) Population trend of the world's monitored seabirds, 1950-2010. PLoS One 10:e129342. https://doi.org/10.1371/journal.pone.0129342

Patrick SC, Weimerskirch H (2014) Personality, foraging and fitness consequences in a long lived seabird. PLoS One 9:e87269. https:// doi.org/10.1371/journal.pone.0087269

Patrick SC, Bearhop S, Grémillet D et al (2013) Individual differences in searching behaviour and spatial foraging consistency in a central place marine predator. Oikos 123:33-40. https://doi. org/10.1111/j.1600-0706.2013.00406.x

Patrick SC, Bearhop S, Bodey TW et al (2015) Individual seabirds show consistent foraging strategies in response to predictable fisheries discards. J Avian Biol 46:431-440. https://doi.org/10.1111/ jav.00660

Patterson TA, McConnell BJ, Fedak MA et al (2010) Using GPS data to evaluate the accuracy of state-space methods for correction of Argos satellite telemetry error. Ecology 91:273-285. https://doi. org/10.1890/08-1480.1

Pavlov VV, Wilson RP, Lucke K (2007) A new approach to tag design in dolphin telemetry: computer simulations to minimise deleterious effects. Deep Res Part II 54:404-414. https://doi.org/10.1016/j. dsr2.2006.11.010

Pendoley KL, Schofield G, Whittock PA et al (2014) Protected species use of a coastal marine migratory corridor connecting marine protected areas. Mar Biol 161:1455-1466. https://doi.org/10.1007/ s00227-014-2433-7

Phillips RA, Xavier JC, Croxall JP (2003) Effects of satellite transmitters on albatrosses and petrels. Auk 120:1082-1090 
Phillips RA, Silk JRD, Croxall JP et al (2004) Accuracy of geolocation estimates for flying seabirds. Mar Ecol Prog Ser 266:265-272. https://doi.org/10.3354/meps266265

Piatt JF, Sydeman W, Wiese F (2007) Introduction: a modern role for seabirds as indicators. Mar Ecol Prog Ser 352:199-204

Pinaud D, Weimerskirch H (2007) At-sea distribution and scaledependent foraging behaviour of petrels and albatrosses: a comparative study. J Anim Ecol 76:9-19. https://doi. org/10.1111/j.1365-2656.2006.01186.x

Pinaud D, Cherel Y, Weimerskirch H (2005) Effect of environmental variability on habitat selection, diet, provisioning behaviour and chick growth in yellow-nosed albatrosses. Mar Ecol Prog Ser 298:295-304. https://doi.org/10.3354/meps298295

Pistorius P, Hindell M, Crawford R et al (2017) At-sea distribution and habitat use in king penguins at sub-Antarctic Marion Island. Ecol Evol 7:3894-3903. https://doi.org/10.1002/ece3.2833

Ponganis PJ (2013) Diving physiology. J Exp Biol 2016:3381-3383. https://doi.org/10.1242/jeb.076455

Ponganis PJ, Van Dam RP, Marshall G et al (2000) Sub-ice foraging behavior of emperor penguins. J Exp Biol 203:3275-3278

Priede IG (1984) A basking shark (Cetorhinus maximus) tracked by satellite together with simultaneous remote sensing. Fish Res 2:201216. https://doi.org/10.1016/0165-7836(84)90003-1

Priede IG, Miller PI (2009) A basking shark (Cetorhinus maximus) tracked by satellite together with simultaneous remote sensing II: new analysis reveals orientation to a thermal front. Fish Res 95:370-372. https://doi.org/10.1016/j.fishres.2008.09.038

Putman NF, Scanlan MM, Billman EJ et al (2014) An inherited magnetic map guides ocean navigation in juvenile pacific salmon. Curr Biol 24:446-450. https://doi.org/10.1016/j.cub.2014.01.017

Pyke GH (1984) Optimal foraging theory : a critical review. Annu Rev Ecol Syst 15:523-575

Quinn TP (2005) The behavior and ecology of Pacific salmon and trout. University of Washington Press, Seattle

Raymond B, Lea MA, Patterson T et al (2015) Important marine habitat off east Antarctica revealed by two decades of multi-species predator tracking. Ecography 38:121-129. https://doi.org/10.1111/ ecog.01021

Reisinger RR, Oosthuizen WC, Péron G et al (2014) Satellite tagging and biopsy sampling of killer whales at subantarctic Marion Island: effectiveness, immediate reactions and long-term responses. PLoS One 9:e111835. https://doi.org/10.1371/journal.pone.0111835

Reisinger RR, Keith M, Andrews RD et al (2015) Movement and diving of killer whales (Orcinus orca) at a Southern Ocean archipelago. J Exp Mar Bio Ecol 473:90-102. https://doi.org/10.1016/j. jembe.2015.08.008

Reisinger RR, Raymond B, Hindell MA et al (2018) Habitat modelling of tracking data from multiple marine predators identifies important areas in the Southern Indian Ocean. Divers Distrib. https://doi. org/10.1111/ddi.12702

Rishworth GM, Tremblay Y, Green DB et al (2014) Drivers of timeactivity budget variability during breeding in a pelagic seabird. PLoS One 9:e116544. https://doi.org/10.1371/journal.pone.0116544

Robinson RA, Learmonth JA, Hutson AM et al (2005) Climate change and migratory species. BTO Research Report 414

Robinson PW, Costa DP, Crocker DE et al (2012) Foraging behavior and success of a mesopelagic predator in the northeast Pacific Ocean: insights from a data-rich species, the northern elephant seal. PLoS One 7:e36728. https://doi.org/10.1371/journal.pone.0036728

Ropert-Coudert Y, Kato A (2006) Are stomach temperature recorders a useful tool to determine feeding activity. Polar Biosci 20:63-72

Ropert-Coudert Y, Wilson R (2005) Trends and perspectives in animalattached remote sensing. Front Ecol Environ 3:437-444. https://doi. org/10.1890/1540-9295(2005)003

Ropert-Coudert Y, Kato A, Baudat J et al (2001) Feeding strategies of free-ranging Adélie penguins Pygoscelis adeliae analysed by multi- ple data recording. Polar Biol 24:460-466. https://doi.org/10.1007/ s003000100234

Ropert-Coudert Y, Kato A, Liebsch N et al (2004) Monitoring jaw movements: a cue to feeding activity. Game Wildl Sci 20:1-19

Roquet F, Wunsch C, Forget G et al (2013) Estimates of the Southern Ocean general circulation improved by animal-borne instruments. Geophys Res Lett 40:6176-6180. https://doi. org/10.1002/2013GL058304

Rosen DAS, Gerlinsky CG, Trites AW (2017) Telemetry tags increase the costs of swimming in northern fur seals, Callorhinus ursinus. Mar Mammal Sci. https://doi.org/10.1111/mms.12460

Rosenbaum HC, Maxwell SM, Kershaw F et al (2014) Long-range movement of humpback whales and their overlap with anthropogenic activity in the South Atlantic Ocean. Conserv Biol 28:604615. https://doi.org/10.1111/cobi.12225

Ryan PG, Petersen SL, Peters G et al (2004) GPS tracking a marine predator: the effects of precision, resolution and sampling rate on foraging tracks of African Penguins. Mar Biol 145:215-223. https:// doi.org/10.1007/s00227-004-1328-4

Sakamoto KQ, Sato K, Ishizuka M et al (2009a) Can ethograms be automatically generated using body acceleration data from freeranging birds? PLoS One 4:e5379. https://doi.org/10.1371/journal. pone.0005379

Sakamoto KQ, Takahashi A, Iwata T et al (2009b) From the eye of the albatrosses: a bird-borne camera shows an association between albatrosses and a killer whale in the Southern Ocean. PLoS One 4:e7322. https://doi.org/10.1371/journal.pone.0007322

Sato K, Mitani Y, Cameron MF et al (2003) Factors affecting stroking patterns and body angle in diving Weddell seals under natural conditions. J Exp Biol 206:1461-1470. https://doi.org/10.1242/jeb.00265

Schoener TW (1971) Theory of feeding strategies. Annu Rev Ecol Syst 2:369-404

Scholander PF (1940) Experimental investigations on the respiratory function in diving mammals and birds. Hvalrådets Skr 22:1-131

Shaffer SA, Tremblay Y, Awkerman JA et al (2005) Comparison of light- and SST-based geolocation with satellite telemetry in freeranging albatrosses. Mar Biol 147:833-843. https://doi.org/10.1007/ s00227-005-1631-8

Shamoun-Baranes J, Bouten W, van Loon EE et al (2016) Flap or soar? how a flight generalist responds to its aerial environment. Philos Trans R Soc Lond B 371:415-422. https://doi.org/10.1098/ rstb.2015.0395

Shepard ELC, Wilson RP, Quintana F et al (2008) Identification of animal movement patterns using tri-axial accelerometry. Endanger Species Res 10:47-60. https://doi.org/10.3354/esr00084

Shoji A, Aris-Brosou S, Fayet A et al (2015) Dual foraging and pair coordination during chick provisioning by Manx shearwaters: empirical evidence supported by a simple model. J Exp Biol 218:2116-2123. https://doi.org/10.1242/jeb.120626

Shoji A, Aris-Brosou S, Owen E et al (2016) Foraging flexibility and search patterns are unlinked during breeding in a free-ranging seabird. Mar Biol 163:72. https://doi.org/10.1007/s00227-016-2826-X

Skórka P, Wójcik JD (2008) Habitat utilisation, feeding tactics and age related feeding efficiency in the Caspian Gull Larus cachinnans. J Ornithol 149:31-39. https://doi.org/10.1007/s10336-007-0208-3

Sommerfeld J, Kato A, Ropert-Coudert Y et al (2015) Flexible foraging behaviour in a marine predator, the Masked booby (Sula dactylatra), according to foraging locations and environmental conditions. J Exp Mar Bio Ecol 463:79-86. https://doi.org/10.1016/j. jembe.2014.11.005

Sommerfeld J, Mendel B, Fock HO et al (2016) Combining bird-borne tracking and vessel monitoring system data to assess discard use by a scavenging marine predator, the lesser black-backed gull Larus fuscus. Mar Biol 163:116. https://doi.org/10.1007/s00227-016-2889-8

Sonne C, Teilmann J, Wright AJ et al (2012) Tissue healing in two harbor porpoises (Phocoena phocoena) following long-term satellite 
transmitter attachment. Mar Mammal Sci 28:316-324. https://doi org/10.1111/j.1748-7692.2011.00513.x

Spencer NC, Gilchrist HG, Mallory ML (2014) Annual movement patterns of endangered ivory gulls: the importance of sea ice. PLoS One 9:e115231. https://doi.org/10.1371/journal.pone.0115231

Stienen EWM, Desmet P, Aelterman B et al (2016) GPS tracking data of Lesser Black-backed Gulls and Herring Gulls breeding at the southern North Sea coast. Zookeys 555:115-124. https://doi. org/10.3897/zookeys.555.6173

Stillman RA, West AD, Goss-Custard JD et al (2003) An individual behaviour-based model can predict shorebird mortality using routinely collected shellfishery data. J Appl Ecol 40:1090-1101. https://doi.org/10.1111/j.1365-2664.2003.00853.x

Stillman RA, Railsback SF, Giske J et al (2015) Making predictions in a changing world: the benefits of individual-based ecology. Bioscience 65:140-150. https://doi.org/10.1093/biosci/biu192

Sugishita J, Torres LG, Seddon PJ (2015) A new approach to study of seabird-fishery overlap: connecting chick feeding with parental foraging and overlap with fishing vessels. Glob Ecol Conserv 4:632644. https://doi.org/10.1016/j.gecco.2015.11.001

Takahashi A, Sato K, Naito Y et al (2004) Penguin-mounted cameras glimpse underwater group behaviour. Proc R Soc B 271:S281S282. https://doi.org/10.1098/rsbl.2004.0182

Teilmann J, Larsen F, Desportes G (2007) Time allocation and diving behaviour of harbour porpoises (Phocoena phocoena) in Danish and adjacent waters. J Cetacean Res Manag 9:201-210

Thaxter CB, Lascelles B, Sugar K et al (2012) Seabird foraging ranges as a preliminary tool for identifying candidate marine protected areas. Biol Conserv 156:53-61. https://doi.org/10.1016/j. biocon.2011.12.009

Thaxter CB, Ross-Smith VH, Clark JA et al (2016) Contrasting effects of GPS device and harness attachment on adult survival of Lesser Black-backed Gulls Larus fuscus and Great Skuas Stercorarius skua. Ibis 158:279-290. https://doi.org/10.1111/ibi.12340

Thorrold SR, Afonso P, Fontes J, Braun CD, Santos RS, Skomal GB, Berumen ML (2014) Extreme diving behaviour in devil rays links surface waters and the deep ocean. Nat Commun 5:4274

Tomkiewicz SM, Fuller MR, Kie JG et al (2010) Global positioning system and associated technologies in animal behaviour and ecological research. Philos Trans R Soc Lond B 365:2163-2176. https:// doi.org/10.1098/rstb.2010.0090

Tremblay Y, Bertrand S, Henry RW et al (2009) Analytical approaches to investigating seabird-environment interactions: a review. Mar Ecol Prog Ser 391:153-163. https://doi.org/10.3354/meps08146

van der Hoop JM, Fahlman A, Hurst T et al (2014) Bottlenose dolphins modify behavior to reduce metabolic effect of tag attachment. J Exp Biol 217:4229-4236. https://doi.org/10.1242/jeb.108225

van der Vaart E, Johnston ASA, Sibly RM (2016) Predicting how many animals will be where: how to build, calibrate and evaluate individual-based models. Ecol Modell 326:113-123. https://doi. org/10.1016/j.ecolmodel.2015.08.012

Vandenabeele SP, Wilson RP, Grogan A (2011) Tags on seabirds: how seriously are instrument-induced behaviours considered? Anim Welf 20:559-571

Vandenabeele SP, Shepard EL, Grogan A et al (2012) When three per cent may not be three percent; device-equipped seabirds experience variable flight constraints. Mar Biol 159:1-14. https://doi. org/10.1007/s00227-011-1784-6

Vandenabeele SP, Grundy E, Friswell MI et al (2014) Excess baggage for birds: inappropriate placement of tags on gannets changes flight patterns. PLoS One 9:e92657. https://doi.org/10.1371/journal. pone. 0092657

Villegas-Amtmann S, Jeglinski JWE, Costa DP et al (2013) Individual foraging strategies reveal niche overlap between endangered Galapagos pinnipeds. PLoS One 8:e70748. https://doi.org/10.1371/ journal.pone. 0070748
Vincent C, Mcconnell BJ, Ridoux V et al (2002) Assessment of Argos location accuracy from satellite tags deployed on captive grey seals. Mar Mammal Sci 18:156-166. https://doi. org/10.1111/j.1748-7692.2002.tb01025.x

Volpov BL, Hoskins AJ, Battaile BC et al (2015) Identification of prey captures in Australian fur seals (Arctocephalus pusillus doriferus) using head-mounted accelerometers: field validation with animal-borne video cameras. PLoS One 10:e0128789. https://doi. org/10.1371/journal.pone.0128789

Volpov BL, Rosen DAS, Hoskins AJ et al (2016) Dive characteristics can predict foraging success in Australian fur seals (Arctocephalus pusillus doriferus) as validated by animal-borne video. Biol Open 5:262-271. https://doi.org/10.1242/bio.016659

Votier SC, Bearhop S, Ratcliffe N et al (2004) Reproductive consequences for great skuas specializing as seabird predators. Condor 106:275-287. https://doi.org/10.1650/7261

Votier SC, Bearhop S, Witt MJ et al (2010) Individual responses of seabirds to commercial fisheries revealed using GPS tracking, stable isotopes and vessel monitoring systems. J Appl Ecol 47:487-497. https://doi.org/10.1111/j.1365-2664.2010.01790.x

Votier SC, Bicknell A, Cox SL et al (2013) A bird's eye view of discard reforms: bird-borne cameras reveal seabird/fishery interactions. PLoS One 8:e57376. https://doi.org/10.1371/journal.pone.0057376

Walker BG, Boveng PL (1995) Effects of time-depth recorders on maternal foraging and attendance behavior of Antarctic fur seals (Arctocephalus gazella). Can J Zool 73:1538-1544. https://doi. org/10.1139/z95-182

Watanabe Y, Takahashi A (2013) Linking animal-borne video to accelerometers reveals prey capture variability. Proc Natl Acad Sci U S A 110:2199-2204. https://doi.org/10.1073/pnas.1216244110

Watanabe Y, Mitani Y, Sato K et al (2003) Dive depths of Weddell seals in relation to vertical prey distribution as estimated by image data. Mar Ecol Prog Ser 252:283-288. https://doi.org/10.3354/ meps 252283

Watanabe Y, Bornemann H, Liebsch N et al (2006) Seal-mounted cameras detect invertebrate fauna on the underside of an Antarctic ice shelf. Mar Ecol Prog Ser 309:297-300. https://doi.org/10.3354/ meps 309297

Watanuki Y, Daunt F, Takahashi A et al (2008) Microhabitat use and prey capture of a bottom-feeding top predator, the European shag, shown by camera loggers. Mar Ecol Prog Ser 356:283-293. https:// doi.org/10.3354/meps07266

Weimerskirch H, Åkesson S, Pinaud D (2006) Postnatal dispersal of wandering albatrosses Diomedea exulans: implications for the conservation of the species. J Avian Biol 37:23-28. https://doi. org/10.1111/j.2006.0908-8857.03675.x

Weimerskirch H, Pinaud D, Pawlowski F et al (2007) Does prey capture induce area-restricted search? a fine-scale study using GPS in a marine predator, the wandering albatross. Am Nat 170:734-743. https://doi.org/10.1086/522059

Weimerskirch H, Louzao M, de Grissac S et al (2012) Changes in wind pattern alter albatross distribution and life-history traits. Science 335:211-214. https://doi.org/10.1126/science.1210270

Weimerskirch H, Cherel Y, Delord K et al (2014) Lifetime foraging patterns of the wandering albatross: life on the move! J Exp Mar Bio Ecol 450:68-78. https://doi.org/10.1016/j.jembe.2013.10.021

Weinrich M (1998) Early experience in habitat choice by Humpback whales (Megaptera novaeangliae). J Mamm 79:163-170

Weller D (2008) Report of the large whale tagging workshop. U.S. Marine Mammal Commission, San Diego

Weng KC, Castilho PC, Morrissette JM et al (2005) Satellite tagging and cardiac physiology reveal niche expansion in salmon sharks. Science 310:104-106. https://doi.org/10.1126/science.1114616

Wikelski M, Tertitski G (2016) Living sentinels for climate change effects. Science 352:775-776. https://doi.org/10.1126/science. aaf6544 
Wikelski M, Kays RW, Kasdin NJ et al (2007) Going wild: what a global small-animal tracking system could do for experimental biologists. J Exp Biol 210:181-186. https://doi.org/10.1242/jeb.02629

Williams HJ, Holton MD, Shepard ELC et al (2017) Identification of animal movement patterns using tri-axial magnetometry. Mov Ecol 5:6. https://doi.org/10.1186/s40462-017-0097-x

Wilson RP (1997) A method for restraining penguins. Mar Ornithol 25:72-73

Wilson RP (2010) Resource partitioning and niche hyper-volume overlap in free-living Pygoscelid penguins. Funct Ecol 24:646-657. https://doi.org/10.1111/j.1365-2435.2009.01654.x

Wilson RP, McMahon CR (2006) Measuring devices on wild animals: what contitutes acceptable practice? Front Ecol Environ 4:147-154

Wilson RP, Grant WS, Duffy DC (1986) Recording devices on freeranging marine animals: does measurement affect foraging performance? Ecol Soc Am 67:1091-1093

Wilson RP, Cooper J, Plötz J (1992) Can we determine when marine endotherms feed? a case study with seabirds. J Exp Biol 167:267-275

Wilson RP, Steinfurth A, Ropert-Coudert Y et al (2002) Lip-reading in remote subjects: an attempt to quantify and separate ingestion, breathing and vocalisation in free-living animals using penguins as a model. Mar Biol 140:17-27. https://doi.org/10.1007/ s002270100659

Wilson RP, White CR, Quintana F et al (2006) Moving towards acceleration for estimates of activity-specific metabolic rate in free-living animals: the case of the cormorant. J Anim Ecol 75:1081-1090. https://doi.org/10.1111/j.1365-2656.2006.01127.x

Wilson RP, Liebsch N, Davies IM et al (2007) All at sea with animal tracks; methodological and analytical solutions for the resolution of movement. Deep Res Part II 54:193-210. https://doi.org/10.1016/j. dsr2.2006.11.017

Wilson RP, Shepard ELC, Liebsch N (2008) Prying into the intimate details of animal lives: use of a daily diary on animals. Endanger Species Res 4:123-137. https://doi.org/10.3354/esr00064

Wilson ADM, Wikelski M, Wilson RP et al (2015a) Utility of biological sensor tags in animal conservation. Conserv Biol 29:1065-1075. https://doi.org/10.1111/cobi.12486

Wilson RP, Liebsch N, Gómez-Laich A et al (2015b) Options for modulating intra-specific competition in colonial pinnipeds: the case of harbour seals (Phoca vitulina) in the Wadden Sea. PeerJ 3:e957. https://doi.org/10.7717/peerj.957

Wilson K, Littnan C, Halpin P et al (2017) Integrating multiple technologies to understand the foraging behavior of Hawaiian monk seals. R Soc Open Sci 4:160703

Wisniewska DMM, Johnson M, Teilmann J et al (2016) Ultra-high foraging rates of harbor porpoises make them vulnerable to anthropogenic disturbance. Curr Biol 26:1441-1446. https://doi. org/10.1016/j.cub.2016.03.069

Woakes AJ, Butler PJ, Bevan RM (1995) Implantable data logging system for heart rate and body temperature: its application to the estimation of field metabolic rates in Antarctic predators. Med Biol Eng Comput 33:145-151

Zamon JE, Greene CH, Meir E et al (1996) Acoustic characterization of the three-dimensional prey field of foraging chinstrap penguins. Mar Ecol Prog Ser 131:1-10. https://doi.org/10.3354/meps131001

Zooniverse (2017) People-powered research. https://www.zooniverse. org/. Accessed 15 Nov 2017
Open Access This chapter is licensed under the terms of the Creative Commons Attribution 4.0 International License (http://creativecommons.org/licenses/by/4.0/), which permits use, sharing, adaptation, distribution and reproduction in any medium or format, as long as you give appropriate credit to the original author(s) and the source, provide a link to the Creative Commons license and indicate if changes were made.
The images or other third party material in this chapter are included in the chapter's Creative Commons license, unless indicated otherwise in a credit line to the material. If material is not included in the chapter's Creative Commons license and your intended use is not permitted by statutory regulation or exceeds the permitted use, you will need to obtain permission directly from the copyright holder. 